Effect of Extraction Variables on the Bi odegr adabl e Chel ant-Assi st ed Renoval of Toxi c Netal s from Artificial I y Cont ami nated Eur opean Ref er ence Soi Is

\begin{tabular}{|l|l|}
\hline 著者 & $\begin{array}{l}\text { Begum Zi nnat A., Rahnan I snai I M M, Sawai } \\
\text { H kar u, M zut ani Sat oshi, Naki Ter uya, } \\
\text { Hasegawa H r oshi }\end{array}$ \\
\hline $\begin{array}{l}\text { j our nal or } \\
\text { publ i cat i on t i t l e }\end{array}$ & Wat er, Ai r and Soi I Pol I ut i on \\
\hline vol une & 224 \\
\hline nunber & 3 \\
\hline page r ange & $1-21$ \\
\hline year & $2013-03$ 01 \\
\hline URL & ht t p: //hdl . handl e. net /2297/34165 \\
\hline
\end{tabular}




\section{Effect of Extraction Variables on the Biodegradable Chelant-Assisted Removal of Toxic Metals from Artificially Contaminated European Reference Soils}

Zinnat A. Begum, ${ }^{\mathrm{a}, *}$ Ismail M. M. Rahman, ${ }^{\mathrm{a}, \mathrm{b}}$ Hikaru Sawai, ${ }^{\mathrm{a}}$ Satoshi Mizutani, ${ }^{\mathrm{c}}$ Teruya Maki, ${ }^{\mathrm{d}}$ Hiroshi Hasegawa ${ }^{\mathrm{d}, *}$

${ }^{a}$ Graduate School of Natural Science and Technology, Kanazawa University, Kakuma, Kanazawa 920-1192, Japan

${ }^{\mathrm{b}}$ Department of Applied and Environmental Chemistry, University of Chittagong, Chittagong 4331, Bangladesh

${ }^{\text {c }}$ Graduate School of Engineering, Osaka City University, Sugimoto 3-3-138, Sumiyoshi-Ku, Osaka 558-8585, Japan

${ }^{\mathrm{d}}$ Institute of Science and Engineering, Kanazawa University, Kakuma, Kanazawa 920-1192, Japan

*Author(s) for correspondence.

E-mail: Zinnat.Ara@gmail.com (Z.A. Begum); I.M.M.Rahman@gmail.com (I.M.M. Rahman); hhiroshi@t.kanazawa-u.ac.jp (H. Hasegawa). 
Tel/ Fax: +81-76-234-4792

\begin{abstract}
Development of aminopolycarboxylate chelants (APCs) having enhanced biodegradability is gained increasing focus to replace the EDTA and its homologs those used widely for the ex-situ treatment of contaminated soils and are potential eco-threats. The paper reports the chelant-assisted extraction of the toxic metals $(\mathrm{Cd}, \mathrm{Cu}, \mathrm{Pb}$ and $\mathrm{Zn})$ from the metal-spiked European reference soils (Eurosoil 1 and Eurosoil 4) using biodegradable APCs, namely EDDS, GLDA and HIDS. The effects of chelant-to-metal molar ratio, solution $\mathrm{pH}$ and metal-chelant stability constants were evaluated, and compared with that of EDTA. The selectivity aptitude of the biodegradable chelants towards the toxic metals was assumed from the speciation calculations, and a proportionate correlation was observed at neutral $\mathrm{pH}$. Pre- and post-extractive solid phase distributions of the target metals were defined using the sequential extraction procedure and dissolution of metals from the theoretically immobilized fraction was witnessed. The effect of competing species ( $\mathrm{Al}, \mathrm{Ca}, \mathrm{Fe}$, Mg and Mn) concentrations was proven to be minimized with an excess of chelant in solution. The highlight of the outcomes is the superior decontamination ability of GLDA, a biodegradable APC, at minimum chelant concentration in solution and applicability at a wide range of $\mathrm{pH}$ environments.
\end{abstract}

\title{
Keywords
}

Soil remediation; Ex-situ; Eurosoil; Aminopolycarboxylate chelants; Biodegradable; EDDS; GLDA; HIDS; Chelant-to-metal molar ratio; $\mathrm{pH}$; metal-chelant stability constant; Sequential extraction 


\subsection{Introduction}

Contamination of natural soils becomes obvious in recent days due to the increasing chemicalbased agricultural practices, industrial activities and waste disposal (Peters 1999, Dermont et al. 2008a, 2008b). The metal-contaminated soil can either be left as is in the site or can be moved to a secure disposal site with continuous monitoring to limit any possible subsequent contamination (Abumaizar \& Smith 1999). However, the excavation and confinement of soil are no longer considered to be a permanent or economically beneficial option solution (Leštan et al. 2008) and, instead, decontamination of the soil is employed for the re-exploitation of the contaminated sites (Abumaizar \& Smith 1999, Dermont et al. 2008b).

For the treatment of metal-contaminated soils, the available remediation techniques include: solidification/stabilization; in-situ biochemical stabilization (soil amendments with inorganic and organic compounds); soil washing technologies including physical separation methods (such as flotation techniques) and chemical extraction processes (such as acid and chelant extraction); in-situ soil flushing; bioleaching, electrokinetic remediation, and phytoremediation (Mulligan et al. 2001, Virkutyte et al. 2002, Mulligan \& Wang 2006, Löser et al. 2007, Dermont et al. 2008a, 2008b, Kumpiene et al. 2008, Leštan et al. 2008, Vangronsveld et al. 2009, Dermont et al. 2010). Generally, the term 'soil washing' refers as an ex-situ treatment method for separating contaminants from the contaminated media via chemical, physical or physicochemical procedures (Evanko \& Dzombak 1997, Dermont et al. 2008b). The term 'soil flushing' is typically used for describing the in-situ soil washing (Evanko \& Dzombak 1997, Dermont et al. 2008a). The effectiveness of in-situ washing treatment is scarce because the extractants has limited permeability when the soil is in its intact state. Furthermore, site-specific control measures are required to prevent the migration of contaminants into the surrounding groundwater environment (Abumaizar \& Smith 1999). Therefore, the soil washing technique is generally performed as an ex-situ method (Peters 1999). Acids, bases, chelants, surfactants, alcohols, solvents, water, and reducing agents, or other additives are checked as the extracting agent in the soil washing processes (Griffiths 1995). Furthermore, soil washing technology is not limited to the use of washing reagents (i.e. the soil washing technology that uses chemical procedures for dissolving or desorbing the metal 
contaminants in the washing solution). Particle separation method (i.e. the soil washing technology that uses physical procedures for separating the metal contaminants from the soil) is often used as soil washing unit process or in combination with chemical extraction techniques (Dermont et al. 2008a, 2008b). According to recent literature review, the most common applications at field-scale or full/commercial-scale of 'soil washing' technology have been based on physicochemical or particle separation processes rather than chemical extraction processes (Dermont et al. 2008a, 2008b).

The higher costs of chemical-based soil washing, mostly as a consequence of cost of reagents and of the treatment of the washing solutions, limit its application at the commercial scale. However, acid washing and chelant-induced soil washing are the two most recommended metal-contaminated soil remediation methods for practice (Rampley \& Ogden 1998), because those comply better with the factors responsible for the mobilization of metals in soils such as, changes in the acidity, changes in solution ionic strength, changes in the redox potential and formation of complexes (Pickering 1986). The metal sorption capacity of most soils is exceeded when the extent of contamination is very high, and the excess metals get immobilized in the soil by the formation of insoluble precipitates or incorporation into the crystalline structure of soil fractions (Davis \& Singh 1995, Pichtel \& Pichtel 1997). Acids induce an increased solubility of metals through ion exchange and soil matrix dissolution, while it may destroy the basic structure of the soil leaving it unsuitable for further vegetation (Bricka et al. 1993, Peters 1999). Chelants form stable water-soluble complexes with the metals and, therefore, considered as the most effective extractant for the treatment of metal-contaminated soils (Pichtel \& Pichtel 1997, Abumaizar \& Smith 1999, Peters 1999).

Aminopolycarboxylate chelants (APCs), such as EDTA and its homologs, are recommended widely for the ex-situ treatment of contaminated soils and solid waste materials (Leštan et al. 2008, Hasegawa et al. 2010, 2011). However, the use of synthetic APCs (e.g. EDTA) in the soil remediation projects may cause an environmental concern (Nowack 2008). Thus, EDTA must be recycled in order to keep treatment costs at a reasonable level and to avoid the release of EDTA in the environment (Dermont et al. 2008b). The use of bio-surfactants may be an interesting alternative to conventional soil washing reagents (Mulligan \& Wang 2006). Besides, development and 
evaluation of alternative APCs with enhanced biodegradability and less eco-toxicity is considered (Tandy et al. 2004, Hauser et al. 2005, Zhang et al. 2008, Arwidsson et al. 2010a, 2010b). The [S,S]ethylenediaminedisuccinic acid (EDDS) and nitrilotriacetic acid (NTA) are extensively studied as the biodegradable substitute to EDTA (Pichtel \& Pichtel 1997, Vandevivere et al. 2001, Tandy et al. 2004, Hauser et al. 2005), while the use of NTA is restricted due to the risk of adverse health effects (Ebina et al. 1986).

Comparative performances of EDTA with other alternative eco-friendly extractants were reported for the real soil samples from contaminated sites (Pichtel \& Pichtel 1997, Steele \& Pichtel 1998, Tandy et al. 2004, Hauser et al. 2005). The heterogeneity in the sample sources and contaminant inputs produced ambiguous patterns in the corresponding extraction results, and make it difficult to predict a standard performance outline of a chelant. To study the behavior of a new chelant for a particular application, hence, use of artificially contaminated soil is preferred to generate the homogeneity in terms of uniform metal concentration and solid phase fractionation, soil composition, contamination process, and contamination period (Jiang et al. 2011).

In the present study, European (EU) reference soils namely Eurosoil 1 (ES-1) and Eurosoil 4 (ES-4) used as samples, which representatively reflects two of the most frequent and typical soil varieties of the EU-area (Gawlik et al. 2001a). The soils, ES-1 and ES-2, were spiked with the toxic metals ( $\mathrm{Cd}, \mathrm{Cu}, \mathrm{Pb}$ and $\mathrm{Zn})$ and aged to ensure complete and even exposure of every soil particle to the contaminants. The metal-contaminated soil was later treated with the biodegradable APCs namely EDDS, DL-2-(2-carboxymethyl) nitrilotriacetic acid (GLDA) and 3-hydroxy-2,2'iminodisuccinic acid (HIDS). Our research group proposed GLDA and HIDS for ex-situ soil washing application beforehand, and described the corresponding complex formation characteristics with various toxic and non-toxic metal ions (Begum et al. 2012a, 2012b) and appraised for the treatment of 'real' organic-rich metal-contaminated soils (Begum et al. 2012c). As a continuation of our ongoing search of biodegradable APCs for designated applications, we are reporting the applicability of the biodegradable GLDA or HIDS as the alternate to EDTA for the removal of toxic metals from the metal-contaminated EU soils. The prime objective is to understand the standard behavioral outline of GLDA or HIDS at homogeneous conditions, which was not reported before. 
The effects of different extraction variables, such as, concentrations of chelant in solution, $\mathrm{pH}$ conditions, competing species contents in the soil and the metal ion selectivity preferences in terms of the metal-chelant stability constants were considered to explain the APC-induced release pattern of metals from the soil.

\subsection{Experimental}

\subsection{Materials}

\subsubsection{Soil samples}

Two EU reference soils, namely Eurosoil 1 (ES-1) and Eurosoil 4 (ES-4), obtained from ECJRC-IRMM (European Commission Joint Research Centre, Institute of Reference Materials and Measurements) were used. The origins of ES-1 and ES-4, respectively, are Sicily, Italy and Normandy, France, and were collected from a maximum depth of $30 \mathrm{~cm}$ from the specified locations. The soil fractions $<2 \mathrm{~mm}$ were carefully sieved, homogenized and bottled following the procedures as described elsewhere (Gawlik et al. 2001b). The certified and indicative values of the ES-1 and ES-4 soils as obtained from the EC-JRC-IRMM are compiled in Table 1.

\subsubsection{Chemicals}

All the chemicals were of analytical reagent grade and used as received from the manufacturer. Biodegradable chelants used were EDDS (Chelest; Osaka, Japan), GLDA (AkzoNobel; Amsterdam, Netherlands), and HIDS (Nippon Shukubai; Tokyo, Japan). The performances of the biodegradable chelants were compared with that of the EDTA (Wako Pure Chemical; Osaka, Japan). EDTA, a nonbiodegradable synthetic chelant, is recognized as the most effective chelant to remove heavy metals (especially $\mathrm{Cd}, \mathrm{Cu}, \mathrm{Pb}$ and $\mathrm{Zn}$ ) from contaminated soil (Dermont et al. 2008b) and was selected as the reference chelant. Information about the used chelants is compiled in the Table 2.

A PlasmaCAL multi-element solution in $5 \% \mathrm{HNO}_{3}$ (SCP Science; Québec, Canada) was used as the stock solution to prepare the standards for metal concentration measurements. Nitrates of cadmium and copper (Wako Pure Chemical; Osaka, Japan), and Titrisol ampoules of lead and zinc (Merck KGaA; Darmstadt, Germany) were used to prepare the stock solutions of metals for spiking the soils. The stock solutions were diluted with ultrapure water on a weight basis to prepare the 
working solutions ranging from $\mathrm{mM}$ to $\mu \mathrm{M}$. The ultrapure water (resistivity $>18.2 \mathrm{M} \Omega \cdot \mathrm{cm}$ ) that used throughout the experimental process was produced using the Arium Pro water purification system (Sartorius Stedim Biotech GmbH; Göttingen, Germany).

Acetic acid/sodium acetate (HOAc/NaOAc) (Kanto Chemical; Tokyo, Japan), $N$-2hydroxyethylpiperazine- $N$ '-2-ethanesulfonic acid (HEPES) (Nacalai Tesque; Kyoto, Japan), or $N$ cyclohexyl-3-aminopropanesulfonic acid (CAPS) (Sigma-Aldrich; St. Louis, MO) were used as the buffer reagents.

\subsubsection{Laboratory wares}

Low-density polyethylene bottles (Nalge Nunc; Rochester, NY), perfluoroalkoxy tubes and micropipette tips from (Nichiryo; Tokyo, Japan) were used. All the laboratory wares were thoroughly cleaned following the procedure described by Hasegawa et al. (2011).

\subsection{Methods}

\subsubsection{Spiking of soils with metals}

The EC-JRC-IRMM reference soils, ES-1 and ES-4, were spiked with a solution containing 500 $\mu \mathrm{M}$ of $\mathrm{Cd}, \mathrm{Cu}, \mathrm{Pb}$ and $\mathrm{Zn}$ ions. The soil-to-solution ratio was set at 1:5. The soil-solution mixtures were then subjected to the wet-aging process by continuous shaking treatment in an end-over-end shaker at 100 rpm for 10 days. During the wet-aging step, the soil particles were expected to be completely and evenly exposed to the metal contaminant added to the mixture. The suspension was then centrifuged at $3000 \mathrm{rpm}$ for 10 min to separate the soil solids from solution using Kokusan $\mathrm{H}$ 701FR centrifuge (Kokusan Corporation; Tokyo, Japan). The contaminated soil solid fraction was rinsed with the ultrapure water to displace entrapped and loosely bound contaminant ions. The contaminated wet-aged soil was dried in an oven at $70{ }^{\circ} \mathrm{C}$ for $24 \mathrm{~h}$ followed by thorough mixing. The soil was then allowed to be air-dried at room temperature, and the process was completed after 21 days.

\subsubsection{Determination of the metal contents in soils}

The metal contents in the soil samples were determined using the digestion treatments of the soil samples using a Multiwave 3000 microwave reaction system (Anton Paar GmbH; Graz, Austria). 
The pre-cleaned PTFE vessels of the microwave reaction system were fed with $1 \mathrm{~g}$ of the target soil sample and a mixture of $60 \% \mathrm{HNO}_{3}(3 \mathrm{~mL})$ and $36 \% \mathrm{HCl}(9 \mathrm{~mL})$. The suspensions of soil-liquid mixtures obtained after the digestion treatments were filtered through cellulose membrane filters of $0.45 \mu \mathrm{m}$ pore size (Advantec; Tokyo, Japan), and the filtrate was then evaporated on a hot plate at $60{ }^{\circ} \mathrm{C}$ until the total volume reduced to a few milliliters. The resulting concentrates from the evaporation treatment were diluted to a volume of $100 \mathrm{~mL}$ with ultrapure water and stored at $4{ }^{\circ} \mathrm{C}$ until the analysis. The multi-elemental analysis was performed using the iCAP 6300 (Thermo Fisher Scientific; Waltham, MA) inductively coupled plasma optical emission spectrometer (ICP-OES). A blank was treated with the same as the samples, and each of the treatments was performed in triplicates. Total contents of $\mathrm{Cd}, \mathrm{Cu}, \mathrm{Pb}$ and $\mathrm{Zn}$ in the untreated and spiked soil samples are given in Table 3.

\subsubsection{Chelant-assisted extraction of the metals from contaminated soils}

The metal-spiked reference soils, ES-1 and ES-4, were subjected to batch extraction treatments with the biodegradable chelants (EDDS, GLDA and HIDS) and the reference chelant EDTA. Two different chelant concentrations $(0.01$ and $0.05 \mathrm{M})$ were used at a soil-solution ratio of $1: 10(\mathrm{w} / \mathrm{v})$ with varying $\mathrm{pH}$ conditions of 4,7 and 10 . The chelant solutions $\mathrm{pH}$ were maintained using buffer reagents (pH 4: 1 M HOAc/NaOAc, pH 7: 0.1 M HEPES, pH 10: 0.1 M CAPS) and were adjusted using either $\mathrm{HCl}$ or $\mathrm{NaOH}(1 \mathrm{M})$, while the same prepared using ultrapure water only were used as controls. The equivalent chelant: metal $(\mathrm{Cd}+\mathrm{Cu}+\mathrm{Pb}+\mathrm{Zn})$ molar ratios for the different chelant concentrations were ranged from 3 to 16.

Each of the extraction treatments was conducted step by step. In the first step, $1 \mathrm{~g}$ of metalspiked soil sample (ES-1 or ES-4) was added to $10 \mathrm{~mL}$ of chelant solution. In the second step, the soil-chelant solution mixture was shaken for $1 \mathrm{~h}$ at about $30 \mathrm{rpm}$ and at $20 \pm 3^{\circ} \mathrm{C}$ in an end-over-end shaker. In the third step, the solid-solution suspension from the second step was immediately centrifuged for $10 \mathrm{~min}$ at $3000 \mathrm{rpm}$ to separate the supernatant from the solid phase. In the fourth step, the supernatant was passed through a cellulose membrane filter of $0.45 \mu \mathrm{m}$ pore size. The next and final step is the storage of the filtrate at $4{ }^{\circ} \mathrm{C}$ until the analysis using ICP-OES. A set of control experiments were also carried out using ultrapure water as the extractant to determine the water- 
washable metal fraction in the soil samples. Each extraction was performed in triplicates with or without chelant solutions to estimate the reproducibility of the consequences at same circumstances.

The efficiency of the extraction protocol was validated by applying the same to BCR-700 (a naturally contaminated EC-JRC-IRMM reference soil) using EDTA as the extractant at $\mathrm{pH} 7$ and at $20 \pm 3{ }^{\circ} \mathrm{C}$. The results obtained for the EDTA-extractable fractions of BCR-700 were compared with the certified reference values (Table 4). A good operational performance of the applied extraction protocol can be assumed from the coefficients of variation between the certified and experimental values that ranged between 2.6 and $8.4 \%$.

\subsubsection{Fractionation of the metals in the soils before and after chelant-assisted extraction}

The mobility and distribution of the spiked metals in the soils before and after the chelantassisted extraction at neutral $\mathrm{pH}$ condition was explored using the selective sequential extraction (SSE) process, which employs a series of gradually aggressive extractants (Tessier et al. 1979, Maiz et al. 2000, Ph 2002). The SSE scheme was originally proposed by Tessier et al. (1979) to define the metal distribution in the soils into five different fractions, e.g. exchangeable (fraction 1 or F1), bound to carbonates (acid soluble; fraction 2 or F2), bound to iron and manganese oxides (reducible; fraction 3 or F3), bound to organic matter (oxidisable; fraction 4 or F4) and residual (fraction 5 or F5). Digestion treatments of the residue from the SSE process (either before or after chelant-assisted extraction) were conducted to determine the total metal content in the respective soil samples. The compositions of the extraction solutions and the contents of the spiked toxic metals $(\mathrm{Cd}, \mathrm{Cu}, \mathrm{Pb}$ and Zn) in different operationally defined fractions before the chelant-assisted extraction treatment are shown in Table 5.

\subsection{Results and Discussion}

\subsection{Influence of soil properties on the metal distribution}

The properties of the ES-1 and ES-4 soils correspond to the FAO soil unit cambisols and lubisols (Gawlik et al. 2001b), respectively, and are suitable for a wide range of agricultural uses (IUSS Working Group WRB 2007). The clay content (\%) was 3.5 times higher in ES-1 (75.0) than that in the ES-4 (20.3). In terms of pH in water, ES-1 was of mild acidic type while ES-4 was of 
slight basic. The total carbon content $\left(\mathrm{C}_{\text {tot }}\right)$, organic carbon content $\left(\mathrm{C}_{\text {org }}\right)$ and total nitrogen content $\left(\mathrm{N}_{\text {tot }}\right)\left(\mathrm{g} \mathrm{kg}^{-1}\right)$ and effective cation exchange capacity (CEC; $\mathrm{mmol} \mathrm{kg}^{-1}$ ) in ES-4 soil was about 50\% less than that in the ES-1 (Table 1). Although there were marked variations in the soil parameters, the coefficient of variation (\%) in the total uptake of metals in the soils (ES-1 and ES-4) upon spiking treatment was below 4\% (Cu-0.5, Pb-3.1 and $\mathrm{Zn}-3.6)$ except that of $\mathrm{Cd}$ (7.3) (Table 3). Artificial contamination of soils is expected to generate homogeneity among the samples (Jiang et al. 2011), and the comparable total metal contents in the metal-fortified ES-1 and ES-4 soil samples supported the observation.

The total metal content expresses the cumulative amount of metals adsorbed in the soil solid structure, while the leachable metal amount from the contaminated soil samples depends on the modes of metal retention within the soil (Barona et al. 2001). The SSE treatments of the metalspiked ES-1 and ES-4 soils indicate an analogous distribution pattern of Cd in the operationally defined fractions of soil solid phases while the content of the $\mathrm{Cu}, \mathrm{Pb}$ and $\mathrm{Zn}$ are varied to a significant extent (Table 5). The differences in the contents of clay, $\mathrm{C}_{\mathrm{tot}}$ and $\mathrm{C}_{\text {org }}$ between the ES-1 and ES-4 may influence the relative penetration behavior of the metals within the soil structures (Horn et al. 1994, Abumaizar \& Khan 1996, Peters 1999), and may induce the variation in the mobilization of toxic metals $(\mathrm{Cu}, \mathrm{Pb}$ and $\mathrm{Zn})$ in the solid phase fractions of the ES-1 and ES-4. The metal adsorbed in the F1 is the 'most-labile' followed by the contents in the other fractions (F2 > F3 $>$ F4 > F5) in terms of the leachability. Hence, the potential mobility character of the studied toxic metals based on the contents in the $\mathrm{F} 1$ followed the same sequence of $\mathrm{Cd}>\mathrm{Zn}>\mathrm{Pb}>\mathrm{Cu}$ in both ES-1 and ES-4.

\subsection{Influence of the chelant-to-metal molar ratio}

The EDTA, EDDS, GLDA and HIDS are multidentate chelants of non-selective nature and usually form 1:1 molar ratio complexes with most of the heavy metals (Begum et al. 2012a, 2012b). The molar concentration of the chelants is recommended to be greater than that of the target metal species presented in the soil to minimize the competition effect with those of the non-toxic constituents (e.g. $\mathrm{Ca}^{2+}, \mathrm{Fe}^{3+}, \mathrm{Mg}^{2+}, \mathrm{Al}^{3+}$ ) (Leštan et al. 2008, Zou et al. 2009, Begum et al. 2012c). There are reports showing that a ratio $>1$ between the chelant and target metals is sufficient to 
achieve a satisfactory extraction performance (Elliott \& Brown 1989, Tandy et al. 2004). In the present study, two typical EU soil types (ES-1 and ES-4) contaminated with toxic metals (Cd, Cu, $\mathrm{Pb}$ and $\mathrm{Zn}$ ) were treated with the biodegradable chelants (EDDS, GLDA and HIDS) using chelantto-metal molar ratios of $\sim 3$ and $\sim 16$.

The comparative extraction performances of the chelants at varying chelant-to-metal molar ratios and at controlled solution $\mathrm{pH}$ are illustrated in Fig. 1. The impact of the change in the chelant concentrations (0.01 to $0.05 \mathrm{M})$ can be compared using the coefficient of variation (\%) in the extraction rates achieved, as given below in the parentheses:

$$
\begin{aligned}
& \text { ES-1, Cd: HIDS (52) > EDTA (33) EDDS (33) > GLDA (16) (pH 4) } \\
& \text { HIDS (18) > EDDS (4) > GLDA (3) > EDTA (1) (pH 7) } \\
& \text { HIDS (30) > EDDS (12) > EDTA (11) > GLDA (9) }(\mathrm{pH} 10) \\
& \text { ES-4, Cd: HIDS (35) > EDDS (22) > EDTA (17) > GLDA (11) }(\mathrm{pH} 4) \\
& \text { EDDS (30) > HIDS (22) > GLDA (12) > EDTA (6) }(\mathrm{pH} 7) \\
& \text { EDDS }(27)>\operatorname{HIDS}(22)>\operatorname{GLDA}(8)>\operatorname{EDTA}(<1)(\mathrm{pH} 10)
\end{aligned}
$$

ES-1, Cu: HIDS (39) > EDTA (36) > EDDS (22) > GLDA (15) (pH 4)

$$
\begin{aligned}
& \operatorname{EDTA}(7)>\operatorname{GLDA}(3)>\operatorname{EDDS}(2)>\operatorname{HIDS}(1)(\mathrm{pH} 7) \\
& \operatorname{EDTA}(15)>\operatorname{HIDS}(9)>\operatorname{EDDS}(7)>\operatorname{GLDA}(6)(\mathrm{pH} \mathrm{10})
\end{aligned}
$$

ES-4, Cu: EDTA (21) > HIDS (19) > GLDA (7) > EDDS (6) (pH 4)

$$
\begin{aligned}
& \text { EDTA (8) HIDS (8) > EDDS (7) GLDA (7) }(\mathrm{pH} 7) \\
& \operatorname{EDDS~(12)~>~GLDA~(7)~>~HIDS~(6)~>~EDTA~(2)~}(\mathrm{pH} \mathrm{10)}
\end{aligned}
$$

ES-1, Pb: EDDS (62) > HIDS (55) > EDTA (39) > GLDA (23) $(\mathrm{pH} 4)$

$$
\begin{aligned}
& \text { EDDS (8) > EDTA (4) GLDA (4) > HIDS (3) }(\mathrm{pH} 7) \\
& \operatorname{HIDS}(22)>\operatorname{EDDS}(16)>\operatorname{EDTA}(14)>\operatorname{GLDA}(8)(\mathrm{pH} \mathrm{10})
\end{aligned}
$$

ES-4, Pb: EDDS (54) > HIDS (36) > EDTA (27) > GLDA (16) $(\mathrm{pH} 4)$

$$
\begin{aligned}
& \text { EDDS (42) > HIDS (26) > GLDA (21) > EDTA (11) }(\mathrm{pH} \mathrm{7)} \\
& \text { EDDS (28) >> HIDS (17) > EDTA (15) > GLDA (3) }(\mathrm{pH} \mathrm{10)}
\end{aligned}
$$

ES-1, Zn: HIDS (43) > EDDS (32) > EDTA (31) > GLDA (11) $(\mathrm{pH} 4)$ 


$$
\begin{aligned}
& \operatorname{EDTA}(1)>\operatorname{EDDS}(<1) \sim \operatorname{GLDA}(<1) \sim \operatorname{HIDS}(<1)(\mathrm{pH} 7) \\
& \operatorname{HIDS}(13)>\operatorname{EDTA}(8)>\operatorname{EDDS}(6)>\operatorname{GLDA}(3)(\mathrm{pH} 10)
\end{aligned}
$$

ES-4, Zn: EDDS (22) > HIDS (21) > EDTA (18) > GLDA (9) $(\mathrm{pH} 4)$

$$
\begin{aligned}
& \text { EDDS (18) > HIDS (10) > GLDA (8) > EDTA (6) }(\mathrm{pH} 7) \\
& \operatorname{EDDS~}(20)>\operatorname{GLDA~}(9) \sim \operatorname{HIDS}(9)>\operatorname{EDTA}(3)(\mathrm{pH} \mathrm{10)}
\end{aligned}
$$

A minimum variance in the coefficient of variation (\%) indicates a negligible or least impact due to the application of increased chelant doses while a higher difference specifies the reverse. The general trend is that the application of increased chelant-to-molar ratio results in increases in the metal extraction rates (\%). Such a consistent increment in extraction rates with increased chelant dosing is a common phenomenon (Papassiopi et al. 1999, Tandy et al. 2004). There are some exceptions in the results showing minimum effect (coefficient of variation is $\leq 1 \%$ ) on the removal efficiency of the chelants with the increasing doses e.g. $\mathrm{Cu}$ with HIDS and $\mathrm{Zn}$ with all the biodegradable chelants at pH 7 (ES-1) and Cd with EDTA at pH 10 (ES-4). It can be explained by assuming that the chelant dose was above the requirement of soil (Elliott \& Brown 1989, Steele \& Pichtel 1998, Zou et al. 2009).

The variation with the change of solution $\mathrm{pH}$ is commonly uppermost for $\mathrm{pH} 4$ followed by those observed for $\mathrm{pH} 10$ and then $\mathrm{pH}$ 7, i.e. the effect of increasing chelant application is somewhat minimized when the solution $\mathrm{pH}$ is maintained to neutral. Metal extraction from ES-1 soil is improved better than that of the ES-4 soil with the increase of chelant doses; hence, a stronger binding of metal species within the soil solid phases of ES-1 can be assumed. The extraction performance of chelants is improved with the increasing chelant-to-metal molar ratio at a significant rate with EDDS and HIDS, mostly. The notable extraction efficiency of GLDA among all the chelants with the application of minimum chelant dose $(0.01 \mathrm{M})$ was observed in the most number of cases (54\% of the total 24) followed by EDTA, EDDS and HIDS in a respective order regardless of the $\mathrm{pH}$ conditions or soil types.

\subsection{Influence of the extractant solution $\mathrm{pH}$}

Extractant solution $\mathrm{pH}$ can influence the retention capability of the metal adsorbed in soil (Peters 1999). Furthermore, it can affect the mechanisms of contaminant extraction from soil by 
controlling the metal species concentration in the aqueous state, the solubility of chelants in solution, sorption or desorption and ion-exchange behavior of the metals (Kim \& Ong 1999, Lim et al. 2004, Polettini et al. 2007, Zou et al. 2009). A significant enhancement in the metal extractions with chelants was easily-achieved at chelant-excess $(0.05 \mathrm{M})$ conditions, hence, discussed in detail in this section. The observations, as illustrated in Fig. 2, indicate a substantial metal mobilization capability of the chelants with a varying effect on the extraction efficiencies due to the solution $\mathrm{pH}$.

In the control runs with ultrapure water, the metal extraction rate was below $5 \%$ in most cases with some exceptions observed at $\mathrm{pH} 4$, which correspond to the negligible amount of water-soluble content of $\mathrm{Cd}, \mathrm{Cu}, \mathrm{Pb}$ and $\mathrm{Zn}$ in the fortified soil samples. At least, $86 \%$ of the target metal contents were extracted at the chelant-rich condition at $\mathrm{pH} 4$ while some exceptions observed for EDDS and HIDS. GLDA performed better than EDTA or other biodegradable chelants for the extraction of Cd, $\mathrm{Cu}$ and $\mathrm{Zn}$ at $\mathrm{pH} 4$ irrespective of the soil types, while EDTA showed up superior efficiency for the separation of $\mathrm{Pb}$. The rate of metal extraction at $\mathrm{pH} 7$ with the use of $0.05 \mathrm{M}$ chelant solution was typically about $80 \%$. The metal extraction efficiencies of the chelants for both the ES-1 and ES-4 soils followed similar orders: Cd- EDTA > GLDA > EDDS > HIDS; Cu- EDDS EDTA > GLDA $>$ HIDS; Pb- EDTA > EDDS > GLDA > HIDS; Zn- EDTA > EDDS > GLDA > HIDS. EDDS displayed best extraction efficiencies among the biodegradable chelants for the extraction of $\mathrm{Cu}, \mathrm{Pb}$ and $\mathrm{Zn}$ at neutral $\mathrm{pH}$ conditions, and the Cd extraction was optimum with GLDA. The extraction rates at $\mathrm{pH} 10$ ( 90\%) was better as compared to those observed for $\mathrm{pH} 7$ while comparable with the same of $\mathrm{pH} 4$ in many cases. The chelant-induced metal-extraction rates at $\mathrm{pH} 10$ with EDDS were either better or comparable to that of GLDA or HIDS in maximum cases, while the extraction of $\mathrm{Pb}$ remained lower than the other target metals with the latter ones.

The averaged extraction rates at neutral condition $(\mathrm{pH} 7)$ is either lower or comparable than that of the acidic $(\mathrm{pH} 4)$ or alkaline $(\mathrm{pH} \mathrm{10)} \mathrm{conditions,} \mathrm{which} \mathrm{is} \mathrm{attributable} \mathrm{to} \mathrm{the} \mathrm{lesser} \mathrm{solubility} \mathrm{of}$ oxides and other solid phases through the formation of metal hydroxy complexes (Elliott \& Brown 1989). On the contrary, a higher metal extraction efficiency at acidic $\mathrm{pH}$ is likely either caused by the concurrent release of the retained metal species and an exchange of the $\mathrm{H}^{+}$from the soil surface functional groups (Stumm 1992, Lim et al. 2004), or an increased solubility rate of the carbonate- 
bound metals (Vandevivere et al. 2001). The increased extraction at alkaline conditions is caused by the increase of the reactive species $\mathrm{L}^{\mathrm{n}-}$ in solution, which results in higher formation rate of the soluble coordination compounds of the chelants (Fischer \& Bipp 2002).

\subsection{Influence of the metal-chelant stability constants}

Chelants form soluble complexes with the metals, and the corresponding stability of those complexes in solution is one of the key parameters for considering a chelant as a solvent in any chelant-based washing scheme (Nowack 2002). The fundamental stability characteristics of a metalchelant (ML) complex in solution can be assumed from its stability constant ( $\left.\log K_{\mathrm{ML}}\right)$ value (Martell \& Hancock 1996). The corresponding complexes of the ML systems $\left(\mathrm{M}=\mathrm{Cd}^{2+}, \mathrm{Cu}^{2+}, \mathrm{Pb}^{2+}, \mathrm{Zn}^{2+}, \mathrm{L}\right.$ $=$ EDTA, EDDS, GLDA, HIDS) have the following $\log K_{\mathrm{ML}}$ sequences: (a) EDTA: $\log K_{\mathrm{CuL}}>$ $\log K_{\mathrm{PbL}}>\log K_{\mathrm{ZnL}} \sim \log K_{\mathrm{CdL}}$, (b) EDDS: $\log K_{\mathrm{CuL}}>\log K_{\mathrm{ZnL}}>\log K_{\mathrm{PbL}}>\log K_{\mathrm{CdL}}$, (c) GLDA and HIDS: $\log K_{\mathrm{CuL}}>\log K_{\mathrm{PbL}}>\log K_{\mathrm{ZnL}}>\log K_{\mathrm{CdL}}$ (Table 2). Since the other correlated factors (e.g. $\mathrm{pH}$ or interfering effects from the species derived from the side reactions) are ignored during the calculation of $\log K_{\mathrm{ML}}$, 'conditional stability constant (log $\left.K^{\prime}{ }_{\mathrm{ML}}\right)$ ' is defined to measure the relative strength of the actual metal-chelant species present in the aqueous systems at different equilibrium conditions (Davidge et al. 2001). The $\log K^{\prime}{ }_{M L}$ of the ML complexes was calculated using HySS2009 (Alderighi et al. 1999) in terms of the $\mathrm{H}^{+}$ion activity in solution (Table 2). The selectivity aptitude of the chelants towards the metal ions in terms of the change in the $\log K^{\prime}{ }_{M L}$ of the ML complexes is shown in Fig. 3.

A chelant is considered suitable for practical use having the $\log K^{\prime}{ }_{M L}>6$ (Orama et al. 2002) and, accordingly, the biodegradable chelants are unsuitable for the separation of the target metals other than $\mathrm{Cu}$ at the $\mathrm{pH}<5$. Therefore, the metal extraction performance perceived at $\mathrm{pH} 4$ for EDDS, GLDA, HIDS cannot be associated with the stability of $\mathrm{ML}$ complexes $\left(\mathrm{M}=\mathrm{Cd}^{2+}, \mathrm{Pb}^{2+}\right.$, $\mathrm{Zn}^{2+}$ ) in solution (Fig. 3). Instead, the factors those controls the interaction between the chelant solution and the metal constituents of the contaminated soil at acidic $\mathrm{pH}$ condition (as stated in detail in the previous section) can be taken into account. The selectivity of the chelants for the formation of $\mathrm{CuL}$ complexes were also not complaints with the usual order. An orderly reduction in the extraction rates occurred in the maximum number of circumstances with the lowering of $\log K^{\prime}{ }_{\mathrm{ML}}$ values at $\mathrm{pH}$ 
7, and the exceptions were typically observed at $0.01 \mathrm{M}$ chelant dosing. The $\log K^{\prime}{ }_{\mathrm{ML}}$ of the $\mathrm{ML}$ complexes and the corresponding extraction patterns can be correlated in very few cases at $\mathrm{pH} 10$. The inconsistencies in the extraction patterns were attributable either to the lower formation rate of metal-EDDS or higher formation rate of metal-GLDA complexes.

The substandard extraction performance of EDDS can be related to the predominant formation of FeEDDS complexes over other metal-EDDS species at lower $\mathrm{pH}$ conditions, lower rate of formation (59\%) of the dominant species $\left(\mathrm{HEDDS}^{3-}\right.$ ) in solution at neutral $\mathrm{pH}$ conditions, and a decreased dissolution of the metal ions due presumably to metal hydroxide precipitation at $\mathrm{pH} \geq 10$ (Hong \& Pintauro 1996, Vandevivere et al. 2001). GLDA generates aqueous acid in the soluble state, which persist in solution over a wide concentration range than the other chelants, can act as a dissolution agent of carbonate formations and also prevents re-precipitation of metal ions on the soil surface favoring the higher extraction efficiency (Wolf et al. 2010, Begum et al. 2012a, 2012b). Furthermore, kinetic hindrance is commonly occurred at a varying extent during the coordination interactions between the metal ions and the multidentate chelants (Nowack 2002), which may take priority over the general extraction preferences.

\subsection{Influence of the solid phase distribution of metals in soil}

The partitioning of metals within the soil solid phase can be correlated with the varying reactivity and behavior of the soil-bound metals towards the extracting solutions (Barona et al. 2001). The fractionation of metals $(\mathrm{Cd}, \mathrm{Cu}, \mathrm{Pb}$ and $\mathrm{Zn})$ in the solid phase of the raw soils and the chelanttreated soils was defined operationally using the SSE scheme, and the impacts of chelant application (EDTA, EDDS, GLDA and HIDS; $\mathrm{pH}=7$ ) on the distributed metal contents are shown in Fig. 4. The cumulative total metal contents obtained from the SSE steps (Table 5) were higher compared to the total amounts derived from the one-step digestion process (Table 3).

The SSE treatment revealed that 99.5, 79.5, 92.8 and $95.2 \%$ of the total $\mathrm{Cd}, \mathrm{Cu}, \mathrm{Pb}$ and $\mathrm{Zn}$ contents in the ES-1 soil were bound in the non-detrial fractions while it was 99.7, 88.8, 95.0 and 98.0\% in the ES-4 soil. The term 'non-detrial' represent the metal contents partitioned cumulatively in the exchangeable (F1), acid-soluble (F2), reducible (F3) and oxidisable (F4) fractions other than those associated with the residual fraction (F5), and are considered easily extractable with the 
application of chelants (Steele \& Pichtel 1998). A significant total of the Cd ( 80\%) was partitioned in the F1, while $~ 48 \%$ of the Zn was in the F2 irrespective of the soil types. The Cu contents were either substantially incorporated in the F4 (ES-1), or remarkably distributed in the F2 and F3 (ES-4). The Pb was equivalently distributed in the F2, F3 and F4 (ES-1) and F2, F3 (ES-4). The metals integrated in the exchangeable fraction (F1) have highest lability among all the fractions, whereas the amount bound to that fraction is insignificant for $\mathrm{Cu}(<3 \%), \mathrm{Pb}(\sim 3 \%)$ and $\mathrm{Zn}(\sim 20 \%)$. The content of metals in F5 is mostly $\leq 5 \%$ and represents the metals incorporated within the crystalline lattice of the soil, which is comparatively lower than those observed for naturally contaminated soils (Tandy et al. 2004, Begum et al. 2012c). It should be noted that the metal contaminants in the 'real polluted soils' are not limited to ionic forms or sorbed metals, but it may be under particulate forms or low soluble forms. In effect, the metal contaminants in the hazardous sites may result from the solid wastes containing high content of metals (e.g. paint fragments rich in $\mathrm{Pb}$, metallurgical/mining/industrial wastes containing heavy metals, bullet fragments from the small arms' firing ranges, etc.) (Dahlin et al. 2002, Dermont et al. 2008a, 2008b, 2010). Hence, the contaminants are not sorbed onto solid particles but the metal-rich particles are randomly distributed in the soil.

A considerable decrease of the toxic metals partitioned in the F1 and F2 to a minimum value of 5\% was observed. The reduction in F1-Cd content was above the indicated least value, which may be due to the maximum accumulation of $\mathrm{Cd}$ in the F1. The extraction rate of F2-Cd and F2-Pb was comparatively low with HIDS and can be linked to the lowest complexation capacity of the HIDS among the chelants towards the corresponding metals. A significant variation can also be noted with the ES-4 soil at $0.01 \mathrm{M}$ chelant dose regarding the decrease of F2-Pb and F2-Zn contents. A large fraction of the total $\mathrm{Pb}$ and $\mathrm{Zn}$ was partitioned in the F2 of ES-4 soil indicating the higher affinity of those metals to that particular soil phase, and the resultant lower extraction performance perhaps pointed toward the incapability of chelants in suppressing that attractive interaction at $0.01 \mathrm{M}$ dose.

Toxic metals partitioned in the F3 (reducible content) was reduced to no less than half of the initial content after the chelant treatment of the contaminated soil in most of the cases. The extractability of HIDS was also comparatively lower for F3-metal contents (Cd, Pb and Zn) except 
for F3-Cu irrespective of the chelant concentration applied, while a similar pattern was evident with EDDS at a low chelant-to-molar ratio. The extraction behavior of HIDS or EDDS for the F3-metals either attributable to the lower complexation ability of the corresponding chelants or the deficient interaction aptitude towards the metals incorporated in that specific segment.

The metal contents in the extracts of F4 and F5 represent, respectively, the less labile fraction bound to the organic matter, humic acids and sulphides, and the most-persistent fraction in the soil solid phases. Hence, the more the content conformed to F4 and F5 fractions the less the total extraction rate of the corresponding metal was expected. A higher rate of accumulation ensued for $\mathrm{Cu}$ (ES-1, 68.9; ES-4, 30.6) and Pb (ES-1, 37.7; ES-4, 19.2) in the corresponding fractions while that of Cd (ES-1, 1.5; ES-4, 0.5) and Zn (ES-1, 11.9; ES-4, 3.5) were negligible. Accordingly, lower extraction rates of $\mathrm{Cu}$ and $\mathrm{Pb}$ with chelants was witnessed than the other target metals. An exception was observed for ES-4 soil at 0.05 chelant dosing, which can be related to its lower $\mathrm{C}_{\text {org }}$ content. Nevertheless, release of toxic metals occurred from the theoretically immobilized fractions of the contaminated soil when treated with the chelants. Such happenings can be attributable to the capability of the organic chelants in inducing mineral dissolution via surface complexation with the metals (Stumm 1992, Sun et al. 2001, Lim et al. 2004). Besides, the mechanism of metal transport from soil to solution is not only reliant on the solid phase incorporation of the metals but also correlated with other related phenomena, e.g. comparative formation rate of the soluble dominant species in solution, precipitation of the metals in the soil solid phase, re-sorption of the metal-chelant complexes in the active surface sites of the soil matrix and so on (Peters 1999, Barona et al. 2001, Tandy et al. 2004).

\subsection{Influence of the coexisting metals in soils}

The pseudo-selectivity behaviors of the APCs towards the toxic cations in a system much influenced by the presence of the coexisting non-toxic metals, e.g. Al, Ca, Fe, $\mathrm{Mg}$ and $\mathrm{Mn}$ (Nowack 2002, Tandy et al. 2004). The total concentrations and solid phase distribution of the coexisting nontoxic metals (Al, Ca, Fe, Mg and Mn) in the raw ES-1 and ES-4 soils are given in Table 6, and the total extractable contents (\%) of the coexisting metals after washing with the ultrapure water (control) and the chelants (EDTA, EDDS, GLDA and HIDS) of neutral pH are listed in Table 7. The 
relative distributions of the coexisting non-toxic metals in the soil solid phases before and after the treatments with chelants of pH 7 are illustrated in Fig. 5.

The water-only washing treatment specified a minimum extraction of the coexisting metals other than the $\mathrm{Ca}$ and $\mathrm{Mg}$, while the chelant-assisted washing ensured a significant transfer of Ca, Mg and Mn from soil to the solution phase (Table 7).

The dissemination of the $\mathrm{Al}$ and $\mathrm{Fe}$ in the F1 was about to null and were extremely low in F2 (< 1\%) in both ES-1 and ES-2 in comparison with the other elements (Table 6), which is most likely because of the strong tendency of these metals to form oxides and hydroxides (Abollino et al. 2006). A considerable amount (\%) of the total Al (ES-1: 81; ES-4: 80) and Fe (ES-1: 73; ES-4: 78) content was immobilized in the residual fraction (F5) of the raw soils. The F5-metal fraction is theoretically difficult to get to via the chelant-assisted washing treatment, and the fact was established from the percentage released contents of the $\mathrm{Al}$ and Fe (Table 7 and Fig. 5). Almost quantitative release of $\mathrm{Al}$ and Fe attached in the F3 and F4 fractions were observed (Fig. 5), which are possibly derived from the dissolution of amorphous and, to a lesser extent, of crystalline oxides (Li et al. 1995, Zhang et al. 1998).

The Mn content partitioned in F3 (fraction that signifies the content bound to Fe and Mn oxides) of ES-4 soil (66\%) was highest among all the operationally defined fractions, and it was 21\% in ES1 soil (Table 6). The release of Mn from F3 was insignificant from both the soils (Fig. 5), which reflects the weakness of the chelants in the dissolution of manganese oxides (Maiz et al. 2000). The extraction of Mn content from ES-1 soil was $\geq 40 \%$ irrespective of the chelant doses applied, while it was in the range of 11 to $43 \%$ for ES-4 soil depending on the chelant content in solution (Table 7). However, the total Mn content in the raw ES-1 or ES-4 soil (Table 6) was ignoble enough, as compared to the other coexisting metal species, to post an assuming possibility of interferences even at the low chelant dose.

The cumulative Ca and Mg contents (\%) in F1 and F2 (ES-1: Ca- 93, Mg- 89; ES-4: Ca- 65, Mg- 88) indicated the availability of the maximum fractions of the total Ca and $\mathrm{Mg}$ contents for extraction with chelants (Table 6). The chelant-assisted extraction behavior of the coexisting metals (Table 7 and Fig. 5) reveals that Ca or Mg can compete with the toxic metals. However, any such 
competing effect may become prominent at the low chelant-to-metal ratio, particularly with the EDDS and HIDS (Table 7 and Fig. 4). The speciation calculations and geochemical modeling specify an adequate availability of the free chelants at a chelant: metal ratio of $\geq 10$ (Tandy et al. 2004, Polettini et al. 2007), and, hence, a higher chelant-to-molar ratio is recommended for eluding the likely consequences from the co-existing interfering metal species.

\subsection{Conclusions}

Batch extraction treatments were performed on two types of EU-reference soils, ES-1 and ES-4, spiked with $\mathrm{Cd}, \mathrm{Cu}, \mathrm{Pb}$ and $\mathrm{Zn}$ to explore the removal of the toxic metals using biodegradable chelant options (EDDS, GLDA and HIDS) alternate to EDTA. The pattern of metal transports in the soils through the artificial contamination process showed a comparable incorporation of Cd while it was dissimilar for $\mathrm{Cu}, \mathrm{Pb}$ and $\mathrm{Zn}$, and the order of total content assimilated in the exchangeable fraction is $\mathrm{Cd}>\mathrm{Zn}>\mathrm{Pb}>\mathrm{Cu}$. Two different chelant-to-molar ratios of 3 and 16, respectively, were used for the metal extractions, and an increased concentration of chelant in solution facilitated higher rate of metal removal. GLDA typically performed better than the other biodegradable options at the low chelant-to-molar ratio, including the reference chelant EDTA, and the order of efficiency was as follows: GLDA > EDTA > EDDS > HIDS. An overall characteristic order of extraction efficiency of the biodegradable chelants at different $\mathrm{pH}$ conditions followed any of the following patterns, e.g. GLDA $>$ HIDS > EDDS, GLDA $>$ EDDS > HIDS or EDDS > GLDA > HIDS. The effect of extractant $\mathrm{pH}$ on the rate of extractions became minor in the presence of an excess of chelant in solution $(0.05 \mathrm{M})$. The formation rate of the metal-chelants complexes in solution assumed to be correlated with the rate of extractions of the corresponding metals at neutral $\mathrm{pH}$ conditions, while the deviations occurred at acidic or basic $\mathrm{pH}$ was presumably attributed to the lower formation efficiency of metal-EDDS complexes or higher formation rate of metal-GLDA. However, mostly the differences of the extractability of the metals at $\mathrm{pH} 7$ and with an excess of chelant in solution was very low, if not insignificant, despite great (more than 5 orders of magnitude) differences of the stability constants. Therefore, the significance of the correlation between extraction degrees and stability constants is contentious. The solid phase fractionation of soils indicates that a minor dissolution of the metal contents from the least-labile residual fraction can be induced with the 
application of chelants. A higher chelant-to-molar ratio ensures the accessibility of free chelant for easy amenability of the target metal species avoiding the possible competition effects from the coexisting metals.

It should be noted that the co-dissolution of soil components during chemical washing treatment may occur, which is critical from the environmental and economic point of view. Besides, the management of washing effluents containing the metals is also an important aspect in the design of soil washing processes. A closed-loop treatment process that ensures the metal recovery from the washing solutions and recycling of the chelant for simultaneous application will reduce the cumulative cost-factor and is, therefore, preferable. Furthermore, although the experiments carried out with spiked soils produce many interesting data, the results do not reflect the diversity and complexity of a real contaminated soil. Therefore, it is necessary to pay a careful attention concerning the extrapolation of the results and the comparison with field case studies.

\section{Acknowledgements}

This research was partially supported by the Grants-in-Aid for Scientific Research (24310056 and 24·02029) from the Japan Society for the Promotion of Science. Additionally, the authors (ZAB and IMMR) wish to thank Mr. Rauful Alam (Department of Organic Chemistry, Stockholm University, Sweden) for his generous support in collecting the literatures. 


\section{References}

Abollino, O., Giacomino, A., Malandrino, M., Mentasti, E., Aceto, M. \& Barberis, R. (2006). Assessment of metal availability in a contaminated soil by sequential extraction. Water Air and Soil Pollution, 173, 315-338.

Abumaizar, R. \& Khan, L. I. (1996). Laboratory investigation of heavy metal removal by soil washing. Journal of the Air \& Waste Management Association, 46, 765-768.

Abumaizar, R. J. \& Smith, E. H. (1999). Heavy metal contaminants removal by soil washing. Journal of Hazardous Materials, 70, 71-86.

Alderighi, L., Gans, P., Ienco, A., Peters, D., Sabatini, A. \& Vacca, A. (1999). Hyperquad simulation and speciation (HySS): A utility program for the investigation of equilibria involving soluble and partially soluble species. Coordination Chemistry Reviews, 184, 311-318.

Arwidsson, Z., Elgh-Dalgren, K., von Kronhelm, T., Sjöberg, R., Allard, B. \& van Hees, P. (2010a). Remediation of heavy metal contaminated soil washing residues with amino polycarboxylic acids. Journal of Hazardous Materials, 173, 697-704.

Arwidsson, Z., Johansson, E., von Kronhelm, T., Allard, B. \& van Hees, P. (2010b). Remediation of metal contaminated soil by organic metabolites from fungi I - Production of organic acids. Water, Air, \& Soil Pollution, 205, 215-226.

Barona, A., Aranguiz, I. \& Elías, A. (2001). Metal associations in soils before and after EDTA extractive decontamination: Implications for the effectiveness of further clean-up procedures. Environmental Pollution, 113, 79-85.

Begum, Z. A., Rahman, I. M. M., Sawai, H., Tate, Y., Maki, T. \& Hasegawa, H. (2012a). Stability constants of $\mathrm{Fe}(\mathrm{III})$ and $\mathrm{Cr}$ (III) complexes with dl-2-(2-carboxymethyl)nitrilotriacetic acid (GLDA) and 3-hydroxy-2,2'-iminodisuccinic acid (HIDS) in aqueous solution. Journal of Chemical \& Engineering Data, (http://dx.doi.org/10.1021/je3005936).

Begum, Z. A., Rahman, I. M. M., Tate, Y., Egawa, Y., Maki, T. \& Hasegawa, H. (2012b). Formation and stability of binary complexes of divalent ecotoxic ions ( $\mathrm{Ni}, \mathrm{Cu}, \mathrm{Zn}, \mathrm{Cd}, \mathrm{Pb})$ with biodegradable aminopolycarboxylate chelants (DL-2-(2-carboxymethyl)nitrilotriacetic acid, GLDA, and 3-hydroxy-2,2'-iminodisuccinic acid, HIDS) in aqueous solutions. Journal of Solution Chemistry, (http://dx.doi.org/10.1007/s10953-012-9901-9).

Begum, Z. A., Rahman, I. M. M., Tate, Y., Sawai, H., Maki, T. \& Hasegawa, H. (2012c). Remediation of toxic metal contaminated soil by washing with biodegradable aminopolycarboxylate chelants. Chemosphere, 87, 1161-1170.

Bricka, R. M., Williford, C. W. \& Jones, L. W. (1993). Technology Assessment of Currently Available and Developmental Technique for Heavy Metals-Contaminated Soils Treatment 
(Technical Report IRRP-93-4). Vicksburg, MS: U.S. Army Corps of Engineers, Waterways Experiment Station.

Dahlin, C. L., Williamson, C. A., Keith Collins, W. \& Dahlin, D. C. (2002). Sequential extraction versus comprehensive characterization of heavy metal species in Brownfield soils. Environmental Forensics, 3, 191-201.

Davidge, J., Thomas, C. P. \& Williams, D. R. (2001). Conditional formation constants or chemical speciation data? Chemical Speciation and Bioavailability, 13, 129-134.

Davis, A. P. \& Singh, I. (1995). Washing of zinc(II) from contaminated soil column. Journal of Environmental Engineering-Asce, 121, 174-185.

Dermont, G., Bergeron, M., Mercier, G. \& Richer-Laflèche, M. (2008a). Metal-contaminated soils: Remediation practices and treatment technologies. Practice Periodical of Hazardous, Toxic, and Radioactive Waste Management, 12, 188-209.

Dermont, G., Bergeron, M., Mercier, G. \& Richer-Laflèche, M. (2008b). Soil washing for metal removal: A review of physical/chemical technologies and field applications. Journal of Hazardous Materials, 152, 1-31.

Dermont, G., Bergeron, M., Richer-Laflèche, M. \& Mercier, G. (2010). Remediation of metalcontaminated urban soil using flotation technique. Science of the Total Environment, 408, 1199-1211.

Ebina, Y., Okada, S., Hamazaki, S., Ogino, F., Li, J. L. \& Midorikawa, O. (1986). Nephrotoxicity and renal cell carcinoma after use of iron- and aluminum-nitrilotriacetate complexes in rats. Journal of the National Cancer Institute, 76, 107-113.

Elliott, H. A. \& Brown, G. A. (1989). Comparative evaluation of NTA and EDTA for extractive decontamination of Pb-polluted soils. Water, Air, \& Soil Pollution, 45, 361-369.

Evanko, C. R. \& Dzombak, D. A. (1997). Remediation of Metals-Contaminated Soils and Groundwater (TE-97-01). Pittsburgh, PA: Ground-Water Remediation Technologies Analysis Center (GWRTAC).

Fischer, K. \& Bipp, H. P. (2002). Removal of heavy metals from soil components and soils by natural chelating agents. Part II. Soil extraction by sugar acids. Water, Air, \& Soil Pollution, 138, 271-288.

Gawlik, B. M., Lamberty, A., Muntau, H. \& Pauwels, J. (2001a). EUROSOILS - A set of CRMs for comparability of soil-measurements. Fresenius' Journal of Analytical Chemistry, 370, 220 223.

Gawlik, B. M., Lamberty, A., Pauwels, J. \& Muntau, H. (2001b). Certification of soil-pH (suspensions of water and $\mathrm{CaCl}_{2}$ ) and adsorption coefficients for atrazine, 2,4-D and lindane 
in six different reference soils (EUROSOILS): IRMM-443. Luxembourg: DirectorateGeneral for Research, European Commission.

Griffiths, R. A. (1995). Soil-washing technology and practice. Journal of Hazardous Materials, 40, 175-189.

Hasegawa, H., Rahman, I. M. M., Kinoshita, S., Maki, T. \& Furusho, Y. (2010). Non-destructive separation of metal ions from wastewater containing excess aminopolycarboxylate chelant in solution with an ion-selective immobilized macrocyclic material. Chemosphere, 79, 193-198.

Hasegawa, H., Rahman, I. M. M., Nakano, M., Begum, Z. A., Egawa, Y., Maki, T., Furusho, Y. \& Mizutani, S. (2011). Recovery of toxic metal ions from washing effluent containing excess aminopolycarboxylate chelant in solution. Water Research, 45, 4844-4854.

Hauser, L., Tandy, S., Schulin, R. \& Nowack, B. (2005). Column extraction of heavy metals from soils using the biodegradable chelating agent EDDS. Environmental Science \& Technology, 39, 6819-6824.

Hong, J. \& Pintauro, P. N. (1996). Desorption-complexation-dissolution characteristics of adsorbed cadmium from kaolin by chelators. Water, Air, \& Soil Pollution, 86, 35-50.

Horn, R., Taubner, H., Wuttke, M. \& Baumgartl, T. (1994). Soil physical properties related to soil structure. Soil and Tillage Research, 30, 187-216.

IUSS Working Group WRB (2007). World Reference Base for Soil Resources 2006, first update 2007. World Soil Resources Reports No. 103. Rome: The Food and Agriculture Organization (FAO).

Jiang, W., Tao, T. \& Liao, Z. (2011). Removal of heavy metal from contaminated soil with chelating agents. Open Journal of Soil Science, 1, 70-76.

Kim, C. \& Ong, S.-K. (1999). Recycling of lead-contaminated EDTA wastewater. Journal of Hazardous Materials, 69, 273-286.

Kumpiene, J., Lagerkvist, A. \& Maurice, C. (2008). Stabilization of As, Cr, Cu, Pb and Zn in soil using amendments - A review. Waste Management, 28, 215-225.

Leštan, D., Luo, C. L. \& Li, X. D. (2008). The use of chelating agents in the remediation of metalcontaminated soils: A review. Environmental Pollution, 153, 3-13.

Li, X., Coles, B. J., Ramsey, M. H. \& Thornton, I. (1995). Chemical partitioning of the new National Institute of Standards and Technology standard reference materials (SRM 2709-2711) by sequential extraction using inductively coupled plasma atomic emission spectrometry. Analyst, 120, 1415-1419.

Lim, T. T., Tay, J. H. \& Wang, J. Y. (2004). Chelating-agent-enhanced heavy metal extraction from a contaminated acidic soil. Journal of Environmental Engineering-Asce, 130, 59-66. 
Löser, C., Zehnsdorf, A., Hoffmann, P. \& Seidel, H. (2007). Remediation of heavy metal polluted sediment by suspension and solid-bed leaching: Estimate of metal removal efficiency. Chemosphere, 66, 1699-1705.

Maiz, I., Arambarri, I., Garcia, R. \& Millán, E. (2000). Evaluation of heavy metal availability in polluted soils by two sequential extraction procedures using factor analysis. Environmental Pollution, 110, 3-9.

Martell, A. E. \& Hancock, R. D. (1996). Metal Complexes in Aqueous Solutions. New York: Plenum Press.

Martell, A. E., Smith, R. M. \& Motekaitis, R. J. (2004). NIST Standard Reference Database 46: NIST Critically Selected Stability Constants of Metal Complexes Database (Version 8.0 For Windows). Texas A\&M University, College Station, TX.

Mulligan, C. N. \& Wang, S. (2006). Remediation of a heavy metal-contaminated soil by a rhamnolipid foam. Engineering Geology, 85, 75-81.

Mulligan, C. N., Yong, R. N. \& Gibbs, B. F. (2001). Remediation technologies for metalcontaminated soils and groundwater: An evaluation. Engineering Geology, 60, 193-207.

Nowack, B. (2002). Environmental chemistry of aminopolycarboxylate chelating agents. Environmental Science \& Technology, 36, 4009-4016.

Nowack, B. (2008). Chelating agents and the environment. Environmental Pollution, 153, 1-2.

Orama, M., Hyvonen, H., Saarinen, H. \& Aksela, R. (2002). Complexation of [S,S] and mixed stereoisomers of $N, N^{\prime}$-ethylenediaminedisuccinic acid (EDDS) with $\mathrm{Fe}(\mathrm{III}), \mathrm{Cu}(\mathrm{II}), \mathrm{Zn}(\mathrm{II})$ and $\mathrm{Mn}(\mathrm{II})$ ions in aqueous solution. Journal of the Chemical Society, Dalton Transactions, 4644-4648.

Papassiopi, N., Tambouris, S. \& Kontopoulos, A. (1999). Removal of heavy metals from calcareous contaminated soils by EDTA leaching. Water, Air, \& Soil Pollution, 109, 1-15.

Peters, R. W. (1999). Chelant extraction of heavy metals from contaminated soils. Journal of Hazardous Materials, 66, 151-210.

$\mathrm{Ph}, \mathrm{Q}$. (2002). Operationally-defined extraction procedures for soil and sediment analysis. Part 3: New CRMs for trace-element extractable contents. Trac-Trends in Analytical Chemistry, 21, 774-785.

Pichtel, J. \& Pichtel, T. M. (1997). Comparison of solvents for ex situ removal of chromium and lead from contaminated soil. Environmental Engineering Science, 14, 97-104.

Pickering, W. F. (1986). Metal ion speciation - Soils and sediments (a review). Ore Geology Reviews, 1, 83-146.

Polettini, A., Pomi, R. \& Rolle, E. (2007). The effect of operating variables on chelant-assisted 
remediation of contaminated dredged sediment. Chemosphere, 66, 866-877.

Pueyo, M., Rauret, G., Bacon, J. R., Gomez, A., Muntau, H., Quevauviller, P. \& F Lopez-Sanchez, J. (2001). A new organic-rich soil reference material certified for its EDTA- and acetic acidextractable contents of $\mathrm{Cd}, \mathrm{Cr}, \mathrm{Cu}, \mathrm{Ni}, \mathrm{Pb}$ and $\mathrm{Zn}$, following collaboratively tested and harmonised procedures. Journal of Environmental Monitoring, 3, 238-242.

Rampley, C. G. \& Ogden, K. L. (1998). Preliminary studies for removal of lead from surrogate and real soils using a water soluble chelator: Adsorption and batch extraction. Environmental Science \& Technology, 32, 987-993.

Rauret, G., Lopez-Sanchez, J. F., Bacon, J., Gomez, A., Muntau, H. \& Quevauviller, P. (2001). Certification of the Contents (Mass Fractions) of $\mathrm{Cd}, \mathrm{Cr}, \mathrm{Cu}, \mathrm{Ni}, \mathrm{Pb}$ and $\mathrm{Zn}$ in an OrganicRich Soil Following Harmonised EDTA and Acetic Acid Extraction Procedures: BCR-700. Luxembourg: Directorate-General for Research, European Commission.

Steele, M. C. \& Pichtel, J. (1998). Ex-situ remediation of a metal-contaminated superfund soil using selective extractants. Journal of Environmental Engineering-Asce, 124, 639-645.

Stumm, W. (1992). Chemistry of the Solid Water Interface: Processes at the Mineral-Water and Particle-Water Interface in Natural Systems. New York: Wiley.

Sun, B., Zhao, F. J., Lombi, E. \& McGrath, S. P. (2001). Leaching of heavy metals from contaminated soils using EDTA. Environmental Pollution, 113, 111-120.

Tandy, S., Bossart, K., Mueller, R., Ritschel, J., Hauser, L., Schulin, R. \& Nowack, B. (2004). Extraction of heavy metals from soils using biodegradable chelating agents. Environmental Science \& Technology, 38, 937-944.

Tessier, A., Campbell, P. G. C. \& Bisson, M. (1979). Sequential extraction procedure for the speciation of particulate trace metals. Analytical Chemistry, 51, 844-851.

Vandevivere, P., Hammes, F., Verstraete, W., Feijtel, T. \& Schowanek, D. (2001). Metal decontamination of soil, sediment, and sewage sludge by means of transition metal chelant [S,S]-EDDS. Journal of Environmental Engineering-Asce, 127, 802-811.

Vangronsveld, J., Herzig, R., Weyens, N., Boulet, J., Adriaensen, K., Ruttens, A., Thewys, T., Vassilev, A., Meers, E., Nehnevajova, E., van der Lelie, D. \& Mench, M. (2009). Phytoremediation of contaminated soils and groundwater: Lessons from the field. Environmental Science and Pollution Research, 16, 765-794.

Virkutyte, J., Sillanpää, M. \& Latostenmaa, P. (2002). Electrokinetic soil remediation - Critical overview. Science of the Total Environment, 289, 97-121.

Wolf, C. A. D., Lepage, J. N. \& Bemelaar, J. H. (2010). Acidic Aqueous Solution Containing a Chelating Agent and the Use Thereof. United States Patent Application Publication. Akzo 
Nobel N.V., USA.

Zhang, L., Zhu, Z., Zhang, R., Zheng, C., Zhang, H., Qiu, Y. \& Zhao, J. (2008). Extraction of copper from sewage sludge using biodegradable chelant EDDS. Journal of Environmental Sciences, 20, 970-974.

Zhang, T., Shan, X. \& Li, F. (1998). Comparison of two sequential extraction procedures for speciation analysis of metals in soils and plant availability. Communications in Soil Science and Plant Analysis, 29, 1023-1034.

Zou, Z., Qiu, R., Zhang, W., Dong, H., Zhao, Z., Zhang, T., Wei, X. \& Cai, X. (2009). The study of operating variables in soil washing with EDTA. Environmental Pollution, 157, 229-236. 
Water, Air, \& Soil Pollution (2013) 224: 1381. DOI: http://dx.doi.org/10.1007/s11270-012-1381-4

Table 1: Soil properties ${ }^{a}$

\begin{tabular}{|c|c|c|c|}
\hline \multirow[t]{2}{*}{ Properties } & \multirow[t]{2}{*}{ Unit } & \multicolumn{2}{|l|}{ Soils } \\
\hline & & Eurosoil 1 & Eurosoil 4 \\
\hline Soil type & FAO soil unit & Vertic cambisol & Orthic luvisol \\
\hline Clay & $\%$ & 75.0 & 20.3 \\
\hline $\mathrm{pH}$ is water & - & $6.21 \pm 0.30$ & $7.5 \pm 0.7$ \\
\hline $\mathrm{pH}$ in $0.01 \mathrm{M} \mathrm{CaCl}_{2}$ & - & $5.65 \pm 0.24$ & $6.8 \pm 0.6$ \\
\hline Total carbon content $\left(\mathrm{C}_{\text {tot }}\right)$ & $\mathrm{g} \mathrm{kg}^{-1}$ & 33.9 & 14.5 \\
\hline Organic carbon content $\left(\mathrm{C}_{\text {org }}\right)$ & $\mathrm{g} \mathrm{kg}^{-1}$ & 32.7 & 13.1 \\
\hline Total nitrogen content $\left(\mathrm{N}_{\mathrm{tot}}\right)$ & $\mathrm{g} \mathrm{kg}^{-1}$ & 3.4 & 1.6 \\
\hline Effective cation exchange capacity (CEC) & mmol kg-1 & $283.2 \pm 3.0$ & $159.0 \pm 5.8$ \\
\hline
\end{tabular}

${ }^{a}$ Extract from report of the EC-JRC-IRMM (European Commission Joint Research Centre, Institute of Reference Materials and Measurements). The methods of measurements are described elsewhere (Gawlik et al. 2001b). Uncertainty in measurements is included wherever mentioned in the EC-JRC-IRMM report. 
Table 2: Chemical structures, acid dissociation constants $\left(\mathrm{p} K_{\mathrm{a}}\right)$ of the chelants, stability constants $\left(\log K_{\mathrm{ML}}\right)$ and conditional stability constants $\left(\log K_{\mathrm{ML}}^{\prime}\right.$ ) (at different $\mathrm{pH}$ ) of metal-chelant complexes, and initial speciation of chelants (at $\mathrm{pH} 7)$ in the assay mixtures (chelant: metal $=1: 1$ )

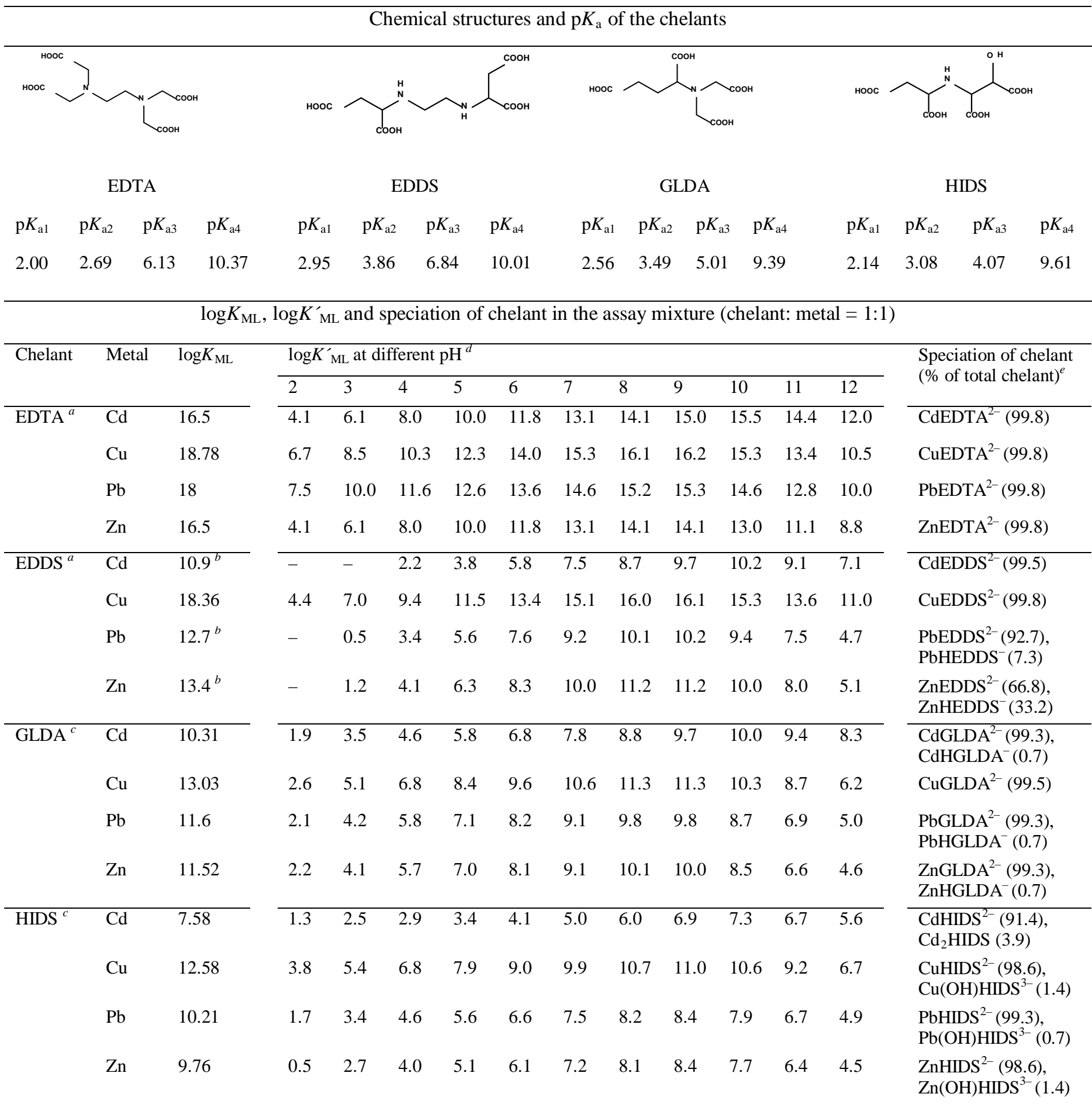

\footnotetext{
${ }^{a}$ At $25^{\circ} \mathrm{C}(\mu=0.1 \mathrm{M})$, (Martell et al. 2004).

${ }^{b}$ At $20^{\circ} \mathrm{C}(\mu=0.1 \mathrm{M})$, (Martell et al. 2004).

${ }^{c}$ At $25^{\circ} \mathrm{C}(\mu=0.1 \mathrm{M})$, (Begum et al. 2012b).

${ }^{d}$ The change in conditional stability constants of various metal-chelant complexes in terms of the solution $\mathrm{pH}$ is calculated with the aid of the computer program HySS2009 (Alderighi et al. 1999).

${ }^{e}$ Initial speciation of chelant in the assay mixture at $\mathrm{pH} 7$ containing the chelant and metal ion (1:1 molar ratio) was calculated using the computer program HySS2009 (Alderighi et al. 1999). Only the two most important chelant species are listed. Other species is not mentioned, when the \% formation of the dominant species is $>99.5$.
} 
Water, Air, \& Soil Pollution (2013) 224: 1381. DOI: http://dx.doi.org/10.1007/s11270-012-1381-4

Table 3: Total contents of the target toxic metals (Cd, $\mathrm{Cu}, \mathrm{Pb}$ and $\mathrm{Zn})$ in the untreated and metal-treated Eurosoil 1 and Eurosoil 4

\begin{tabular}{|c|c|c|c|c|c|}
\hline \multirow[t]{2}{*}{ Metal } & \multirow[t]{2}{*}{ Unit } & \multicolumn{2}{|l|}{ Euro Soil-1 } & \multicolumn{2}{|l|}{ Euro Soil-4 } \\
\hline & & Untreated $^{a}$ & Treated $^{b}$ & Untreated $^{a}$ & Treated $^{b}$ \\
\hline $\mathrm{Cd}$ & $\mathrm{mg} \mathrm{kg}^{-1}$ & $0.8 \pm 0.3$ & $357.7 \pm 7.2$ & $0.2 \pm 0.1$ & $309.2 \pm 5.8$ \\
\hline $\mathrm{Cu}$ & $\mathrm{mg} \mathrm{kg}^{-1}$ & $11.5 \pm 1.4$ & $194.6 \pm 5.3$ & $5.7 \pm 1.6$ & $196.7 \pm 13.4$ \\
\hline $\mathrm{Pb}$ & $\mathrm{mg} \mathrm{kg}^{-1}$ & - & $547.7 \pm 8.0$ & - & $583.2 \pm 17.4$ \\
\hline $\mathrm{Zn}$ & $\mathrm{mg} \mathrm{kg}^{-1}$ & $80.2 \pm 2.5$ & $1448.3 \pm 18.6$ & $32.6 \pm 1.5$ & $1347.1 \pm 13.1$ \\
\hline
\end{tabular}

${ }^{a}$ The raw samples of Eurosoil 1 and Eurosoil 4 as obtained from the EC-JRC-IRMM (European Commission Joint Research Centre, Institute of Reference Materials and Measurements) were subjected to the digestion treatment $(n=3)$ to determine the total metal contents. The bottle containing the soil sample was manually shaken for $5 \mathrm{~min}$ to re-homogenize the content before the treatment. ${ }^{b}$ Raw samples of Eurosoil 1 and Eurosoil 4 were spiked with a solution containing $\mathrm{Cd}, \mathrm{Cu}, \mathrm{Pb}$ and $\mathrm{Zn}$ ions at a soil-to-solution ratio of 1:5. The digestion treatments $(n=3)$ of the metal-treated soils were conducted after completion of the total cycle of spiking process. 
Water, Air, \& Soil Pollution (2013) 224: 1381. DOI: http://dx.doi.org/10.1007/s11270-012-1381-4

Table 4: Validation of the extraction scheme: Comparison of the certified and experimental data of EDTAextractable contents of metals (Cd, $\mathrm{Cu}, \mathrm{Pb}$ and $\mathrm{Zn})$ in BCR-700 ${ }^{a}$

\begin{tabular}{llllll}
\hline Metal & Certified value $\left(\mathrm{mg} \mathrm{kg}^{-1}\right)^{b}$ & & Experimental value $\left(\mathrm{mg} \mathrm{kg}^{-1}\right)^{c}$ & & Coefficient of variation (\%) \\
\cline { 1 - 1 } $\mathrm{Cd}$ & $65.2 \pm 3.5$ & $77.1 \pm 1.3$ & 8.4 \\
$\mathrm{Cu}$ & $89.4 \pm 2.8$ & $84.4 \pm 2.1$ & 2.9 \\
$\mathrm{~Pb}$ & $103 \pm 5$ & $108.5 \pm 4.9$ & 2.6 \\
$\mathrm{Zn}$ & $510 \pm 17$ & $582.4 \pm 12.6$ & 6.6 \\
\hline
\end{tabular}

${ }^{a}$ BCR-700 is a soil reference material from the EC-JRC-IRMM (European Commission Joint Research Centre, Institute of Reference Materials and Measurements).

${ }^{b}$ BCR-700 is certified for EDTA and acetic acid-extractable trace element (Cd, $\mathrm{Cr}, \mathrm{Cu}, \mathrm{Ni}, \mathrm{Pb}$, and $\mathrm{Zn}$ ) contents following collaboratively tested and harmonized procedures (Pueyo et al. 2001, Rauret et al. 2001). The mentioned certified value is for EDTAextractable contents of metals.

${ }^{c}$ EDTA was used as the extractant and the extraction protocol was employed at $\mathrm{pH} 7$ and $20 \pm 3{ }^{\circ} \mathrm{C}(n=3)$. 
Water, Air, \& Soil Pollution (2013) 224: 1381. DOI: http://dx.doi.org/10.1007/s11270-012-1381-4

Table 5: Chemical interpretation, extraction conditions and fractionation of toxic metals (Cd, $\mathrm{Cu}, \mathrm{Pb}$ and $\mathrm{Zn}$ ) in the metal-treated Eurosoil 1 and Eurosoil 4

\begin{tabular}{|c|c|c|c|c|c|c|c|c|c|c|}
\hline \multirow{3}{*}{$\begin{array}{l}\text { Chemical } \\
\text { interpretation }\end{array}$} & \multicolumn{2}{|l|}{ Extraction conditions (for $1 \mathrm{~g}$ of metal-spiked soil) } & \multicolumn{8}{|c|}{ Fractionation of metals (\%) } \\
\hline & \multirow[t]{2}{*}{ Extractants and other conditions } & \multirow[t]{2}{*}{ Duration } & \multicolumn{4}{|l|}{ Eurosoil 1} & \multicolumn{4}{|l|}{ Eurosoil 4} \\
\hline & & & $\mathrm{Cd}$ & $\mathrm{Cu}$ & $\mathrm{Pb}$ & Zn & $\mathrm{Cd}$ & $\mathrm{Cu}$ & $\mathrm{Pb}$ & $\mathrm{Zn}$ \\
\hline Exchangeable & $\begin{array}{l}1 \mathrm{M} \mathrm{MgCl}_{2}(\mathrm{pH} 7 ; 8 \mathrm{~mL}) \text {, continuous } \\
\text { agitation, } 20( \pm 3){ }^{\circ} \mathrm{C}\end{array}$ & $1 \mathrm{~h}$ & $79.9 \pm 2.5$ & $1.6 \pm 0.3$ & $1.3 \pm 0.5$ & $16.5 \pm 3.6$ & $82.1 \pm 3.0$ & $2.7 \pm 0.3$ & $3.3 \pm 0.7$ & $20.1 \pm 2.7$ \\
\hline Acid soluble $^{a}$ & $\begin{array}{l}1 \mathrm{M} \mathrm{NaOAc} \text { (pH 5, adjusted with acetic acid; } \\
8 \mathrm{~mL}) \text {, continuous agitation, } 20( \pm 3)^{\circ} \mathrm{C}\end{array}$ & $5 \mathrm{~h}$ & $13.2 \pm 3.8$ & $14.6 \pm 4.2$ & $30.8 \pm 3.8$ & $47.5 \pm 2.2$ & $12.8 \pm 2.9$ & $29.5 \pm 4.6$ & $38.7 \pm 2.7$ & $47.8 \pm 3.8$ \\
\hline Reducible $^{a}$ & $\begin{array}{l}0.04 \mathrm{M} \mathrm{NH}_{2} \mathrm{OH} \cdot \mathrm{HCl} \text { in } 25 \%(\mathrm{v} / \mathrm{v}) \text { acetic acid } \\
(20 \mathrm{~mL}) \text {, occasional agitation, } 96( \pm 3)^{\circ} \mathrm{C}\end{array}$ & $6 \mathrm{~h}$ & $5.4 \pm 0.7$ & $14.9 \pm 1.0$ & $30.2 \pm 3.8$ & $24.1 \pm 3.1$ & $4.7 \pm 1.2$ & $37.2 \pm 3.8$ & $38.8 \pm 4.7$ & $28.6 \pm 4.8$ \\
\hline \multirow[t]{3}{*}{ Oxidisable $^{a}$} & $\begin{array}{l}0.02 \mathrm{M} \mathrm{HNO}_{3}(3 \mathrm{~mL})+30 \% \mathrm{H}_{2} \mathrm{O}_{2}(\mathrm{pH} 2 \text {, } \\
\left.\text { adjusted with } \mathrm{HNO}_{3} ; 5 \mathrm{~mL}\right) \text {, occasional } \\
\text { agitation, } 85( \pm 3)^{\circ} \mathrm{C}\end{array}$ & $2 \mathrm{~h}$ & $1.0 \pm 0.4$ & $48.4 \pm 3.6$ & $30.5 \pm 4.5$ & $7.0 \pm 1.1$ & $0.2 \pm 0.1$ & $19.4 \pm 0.2$ & $14.2 \pm 3.2$ & $1.5 \pm 0.3$ \\
\hline & $\begin{array}{l}30 \% \mathrm{H}_{2} \mathrm{O}_{2} \text { (pH 2, adjusted with } \mathrm{HNO}_{3} ; 3 \\
\text { mL), intermittent agitation, } 85( \pm 3)^{\circ} \mathrm{C}\end{array}$ & $3 \mathrm{~h}$ & & & & & & & & \\
\hline & $\begin{array}{l}3.2 \mathrm{M} \mathrm{NH}_{4} \mathrm{OAc} \text { in } 20 \%(\mathrm{v} / \mathrm{v}) \mathrm{HNO}_{3}(5 \mathrm{~mL}) \\
\text { continuous agitation, } 85( \pm 3){ }^{\circ} \mathrm{C}\end{array}$ & $30 \mathrm{~min}$ & & & & & & & & \\
\hline Residual & $\mathrm{HNO}_{3}+\mathrm{HCl}$ at a ratio of $1: 3(\mathrm{v} / \mathrm{v})$ & - & $0.5 \pm 0.1$ & $20.5 \pm 0.6$ & $7.2 \pm 1.0$ & $4.8 \pm 2.2$ & $0.3 \pm 0.2$ & $11.2 \pm 4.3$ & $5.0 \pm 0.6$ & $2.0 \pm 0.7$ \\
\hline \multicolumn{3}{|c|}{ Recovery of total metal contents from the solid phase fractions $\left(\mathrm{mg} \mathrm{kg}^{-1}\right)$} & 363.2 & 211.9 & 585.6 & 1535.4 & 337.7 & 218.1 & 627.1 & 1474.0 \\
\hline
\end{tabular}


Water, Air, \& Soil Pollution (2013) 224: 1381. DOI: http://dx.doi.org/10.1007/s11270-012-1381-4

Table 6: Total contents and fractionation of coexisting metals (Al, Ca, Fe, Mg and Mn) in Eurosoil 1 and Eurosoil 4

\begin{tabular}{|c|c|c|c|c|c|c|c|c|c|c|c|c|}
\hline \multirow[t]{3}{*}{ Elements } & \multicolumn{2}{|c|}{ Total contents $\left(\mathrm{mg} \mathrm{kg}^{-1}\right)^{a}$} & \multicolumn{10}{|c|}{ Fractionation of metals (\%) ${ }^{b}$} \\
\hline & \multirow[t]{2}{*}{ Eurosoil 1} & \multirow[t]{2}{*}{ Eurosoil 4} & \multicolumn{5}{|l|}{ Eurosoil 1} & \multicolumn{5}{|l|}{ Eurosoil 4} \\
\hline & & & F1 & F2 & F3 & F4 & F5 & F1 & F2 & F3 & $\mathrm{F} 4$ & F5 \\
\hline $\mathrm{Al}$ & $10083 \pm 71$ & $8503 \pm 31$ & 0 & $0.2 \pm 0.1$ & $3.0 \pm 1.1$ & $15.4 \pm 3.8$ & $81.4 \pm 3.3$ & 0 & $0.1 \pm 0.1$ & $6.0 \pm 1.7$ & $13.4 \pm 3.2$ & $80.5 \pm 4.6$ \\
\hline $\mathrm{Ca}$ & $2525 \pm 22$ & $3407 \pm 45$ & $84.8 \pm 3.1$ & $7.9 \pm 1.5$ & $3.8 \pm 0.4$ & $2.6 \pm 1.8$ & $0.9 \pm 0.4$ & $50.7 \pm 3.2$ & $13.7 \pm 4.2$ & $26.4 \pm 2.8$ & $3.5 \pm 0.4$ & $5.6 \pm 1.7$ \\
\hline $\mathrm{Fe}$ & $32726 \pm 73$ & $14407 \pm 24$ & 0 & $0.1 \pm 0$ & $18.8 \pm 2.9$ & $8.6 \pm 3.1$ & $72.5 \pm 3.9$ & 0 & 0 & $20.1 \pm 3.4$ & $2.0 \pm 0.9$ & $77.9 \pm 3.9$ \\
\hline $\mathrm{Mg}$ & $18571 \pm 71$ & $15949 \pm 52$ & $58.0 \pm 0.6$ & $31.2 \pm 0.4$ & $2.8 \pm 1.7$ & $1.5 \pm 1.0$ & $6.5 \pm 2.9$ & $66.8 \pm 0.1$ & $20.5 \pm 1.5$ & $2.6 \pm 1.9$ & $0.6 \pm 0.2$ & $9.5 \pm 3.3$ \\
\hline $\mathrm{Mn}$ & $218 \pm 4$ & $453 \pm 4$ & $47.6 \pm 4.1$ & $7.3 \pm 1.7$ & $21.3 \pm 3.9$ & $7.5 \pm 0.3$ & $16.3 \pm 3.2$ & $13.2 \pm 4.6$ & $6.7 \pm 2.1$ & $66.2 \pm 4.6$ & $2.7 \pm 0.2$ & $11.2 \pm 4.5$ \\
\hline
\end{tabular}

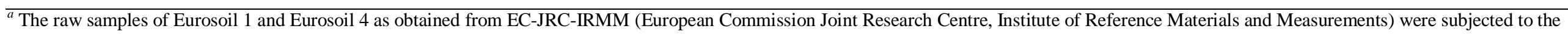
digestion treatment $(n=3)$ to determine the total metal contents. The bottle containing the soil sample was manually shaken for 5 min to re-homogenize the content before the treatment.

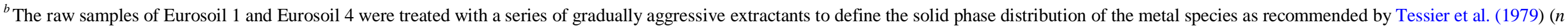

= 3). The extraction conditions are mentioned in Table 5. The details of the different fractions are as follows: F1- exchangeable, F2- acid soluble, F3-reducible, F4- oxidisable, F5- residual. 
Water, Air, \& Soil Pollution (2013) 224: 1381. DOI: http://dx.doi.org/10.1007/s11270-012-1381-4

Table 7: Water- and chelant-extractable fraction of coexisting metals (Al, Ca, Fe, Mg and Mn) in Eurosoil 1 and Eurosoil 4

\begin{tabular}{|c|c|c|c|c|c|c|c|c|c|c|c|c|c|c|c|c|c|c|}
\hline \multirow{4}{*}{ Elements } & \multicolumn{18}{|c|}{ Total extractable fraction of coexisting metals (\%) ${ }^{a}$} \\
\hline & \multicolumn{9}{|c|}{ Eurosoil 1} & \multicolumn{9}{|c|}{ Eurosoil 4} \\
\hline & Control & EDTA & & EDDS & & GLDA & & HIDS & & Control & EDTA & & EDDS & & GLDA & & HIDS & \\
\hline & & $0.01 \mathrm{M}$ & $0.05 \mathrm{M}$ & $0.01 \mathrm{M}$ & $0.05 \mathrm{M}$ & $0.01 \mathrm{M}$ & $0.05 \mathrm{M}$ & $0.01 \mathrm{M}$ & $0.05 \mathrm{M}$ & & $0.01 \mathrm{M}$ & $0.05 \mathrm{M}$ & $0.01 \mathrm{M}$ & $0.05 \mathrm{M}$ & $0.01 \mathrm{M}$ & $0.05 \mathrm{M}$ & $0.01 \mathrm{M}$ & $0.05 \mathrm{M}$ \\
\hline $\mathrm{Al}$ & $4.9 \pm$ & $\begin{array}{l}1.0 \pm \\
0.6\end{array}$ & $\begin{array}{l}1.8 \pm \\
02\end{array}$ & $0.1 \pm$ & $3.4 \pm$ & $1.1 \pm$ & $0.1 \pm$ & $6.5 \pm$ & $2.9 \pm$ & $2.3 \pm$ & $1.8 \pm$ & $0.1 \pm$ & $1.1 \pm$ & $6.1 \pm$ & $1.8 \pm$ & $1.8 \pm$ & $0.6 \pm$ & $17.7 \pm$ \\
\hline $\mathrm{Ca}$ & $\begin{array}{l}31.7 \pm \\
4.8\end{array}$ & $\begin{array}{l}51.3 \pm \\
4.8\end{array}$ & $\begin{array}{l}88.9 \pm \\
3.2\end{array}$ & $\begin{array}{l}30.9 \pm \\
3.8\end{array}$ & $\begin{array}{l}49.3 \pm \\
2.2\end{array}$ & $\begin{array}{l}49.3 \pm \\
4.5\end{array}$ & $\begin{array}{l}80.2 \pm \\
2.1\end{array}$ & $\begin{array}{l}40.3 \pm \\
5.1\end{array}$ & $\begin{array}{l}67.5 \pm \\
1.2\end{array}$ & $\begin{array}{l}17.1 \pm \\
3.5\end{array}$ & $\begin{array}{l}49.6 \pm \\
4.6\end{array}$ & $\begin{array}{l}69.4 \pm \\
1.8\end{array}$ & $\begin{array}{l}15.8 \pm \\
0.8\end{array}$ & $\begin{array}{l}22.8 \pm \\
4.6\end{array}$ & $\begin{array}{l}26.2 \pm \\
2.5\end{array}$ & $\begin{array}{l}2.7 \pm \\
0.6\end{array}$ & $\begin{array}{l}25.0 \pm \\
3.8\end{array}$ & $\begin{array}{l}35.1 \pm \\
1.7\end{array}$ \\
\hline $\mathrm{Fe}$ & $\begin{array}{l}6.8 \pm \\
0.1\end{array}$ & $\begin{array}{l}14.3 \pm \\
0.2\end{array}$ & $\begin{array}{l}21.8 \pm \\
2.7\end{array}$ & $\begin{array}{l}15.8 \pm \\
1.2\end{array}$ & $\begin{array}{l}17.2 \pm \\
4.6\end{array}$ & $\begin{array}{l}15.8 \pm \\
0.2\end{array}$ & $\begin{array}{l}14.8 \pm \\
0.4\end{array}$ & $\begin{array}{l}19.5 \pm \\
0.1\end{array}$ & $\begin{array}{l}9.8 \pm \\
1.4\end{array}$ & $\begin{array}{l}5.4 \pm \\
0.2\end{array}$ & $\begin{array}{l}5.1 \pm \\
1.3\end{array}$ & $\begin{array}{l}6.7 \pm \\
0.4\end{array}$ & $\begin{array}{l}2.2 \pm \\
0.03\end{array}$ & $\begin{array}{l}17.2 \pm \\
2.3\end{array}$ & $\begin{array}{l}4.8 \pm \\
0.3\end{array}$ & $\begin{array}{l}11.9 \pm \\
0.1\end{array}$ & $\begin{array}{l}3.9 \pm \\
0.4\end{array}$ & $\begin{array}{l}25.4 \pm \\
0.3\end{array}$ \\
\hline $\mathrm{Mg}$ & $\begin{array}{l}35.0 \pm \\
4.0\end{array}$ & $\begin{array}{l}32.6 \pm \\
0.4\end{array}$ & $\begin{array}{l}33.2 \pm \\
1.4\end{array}$ & $\begin{array}{l}34.0 \pm \\
2.0\end{array}$ & $\begin{array}{l}30.9 \pm \\
2.6\end{array}$ & $\begin{array}{l}33.1 \pm \\
2.0\end{array}$ & $\begin{array}{l}31.2 \pm \\
3.6\end{array}$ & $\begin{array}{l}33.5 \pm \\
2.7\end{array}$ & $\begin{array}{l}30.4 \pm \\
3.6\end{array}$ & $\begin{array}{l}35.4 \pm \\
1.6\end{array}$ & $\begin{array}{l}36.3 \pm \\
2.6\end{array}$ & $\begin{array}{l}31.1 \pm \\
1.4\end{array}$ & $\begin{array}{l}34.7 \pm \\
3.3\end{array}$ & $\begin{array}{l}33.1 \pm \\
2.2\end{array}$ & $\begin{array}{l}35.2 \pm \\
4.2\end{array}$ & $\begin{array}{l}31.9 \pm \\
4.0\end{array}$ & $\begin{array}{l}33.0 \pm \\
1.6\end{array}$ & $\begin{array}{l}33.0 \pm \\
3.4\end{array}$ \\
\hline $\mathrm{Mn}$ & $\begin{array}{l}16.4 \pm \\
3.7\end{array}$ & $\begin{array}{l}54.8 \pm \\
4.6\end{array}$ & $\begin{array}{l}59.2 \pm \\
1.1\end{array}$ & $\begin{array}{l}46.7 \pm \\
1.5\end{array}$ & $\begin{array}{l}51.7 \pm \\
0.5\end{array}$ & $\begin{array}{l}46.8 \pm \\
3.2\end{array}$ & $\begin{array}{l}50.3 \pm \\
1.7\end{array}$ & $\begin{array}{l}42.2 \pm \\
1.0\end{array}$ & $\begin{array}{l}46.5 \pm \\
0.6\end{array}$ & $\begin{array}{l}5.9 \pm \\
1.8\end{array}$ & $\begin{array}{l}22.4 \pm \\
2.9\end{array}$ & $\begin{array}{l}43.4 \pm \\
2.4\end{array}$ & $\begin{array}{l}11.8 \pm \\
1.2\end{array}$ & $\begin{array}{l}38.4 \pm \\
0.3\end{array}$ & $\begin{array}{l}17.8 \pm \\
2.1\end{array}$ & $\begin{array}{l}38.9 \pm \\
1.2\end{array}$ & $\begin{array}{l}3.4 \pm \\
0.05\end{array}$ & $\begin{array}{l}29.1 \pm \\
0.7\end{array}$ \\
\hline
\end{tabular}

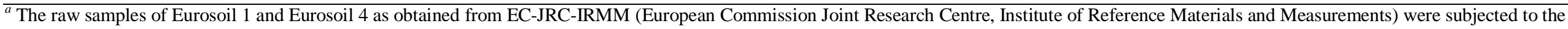

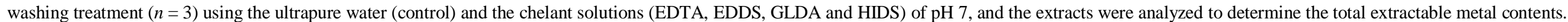




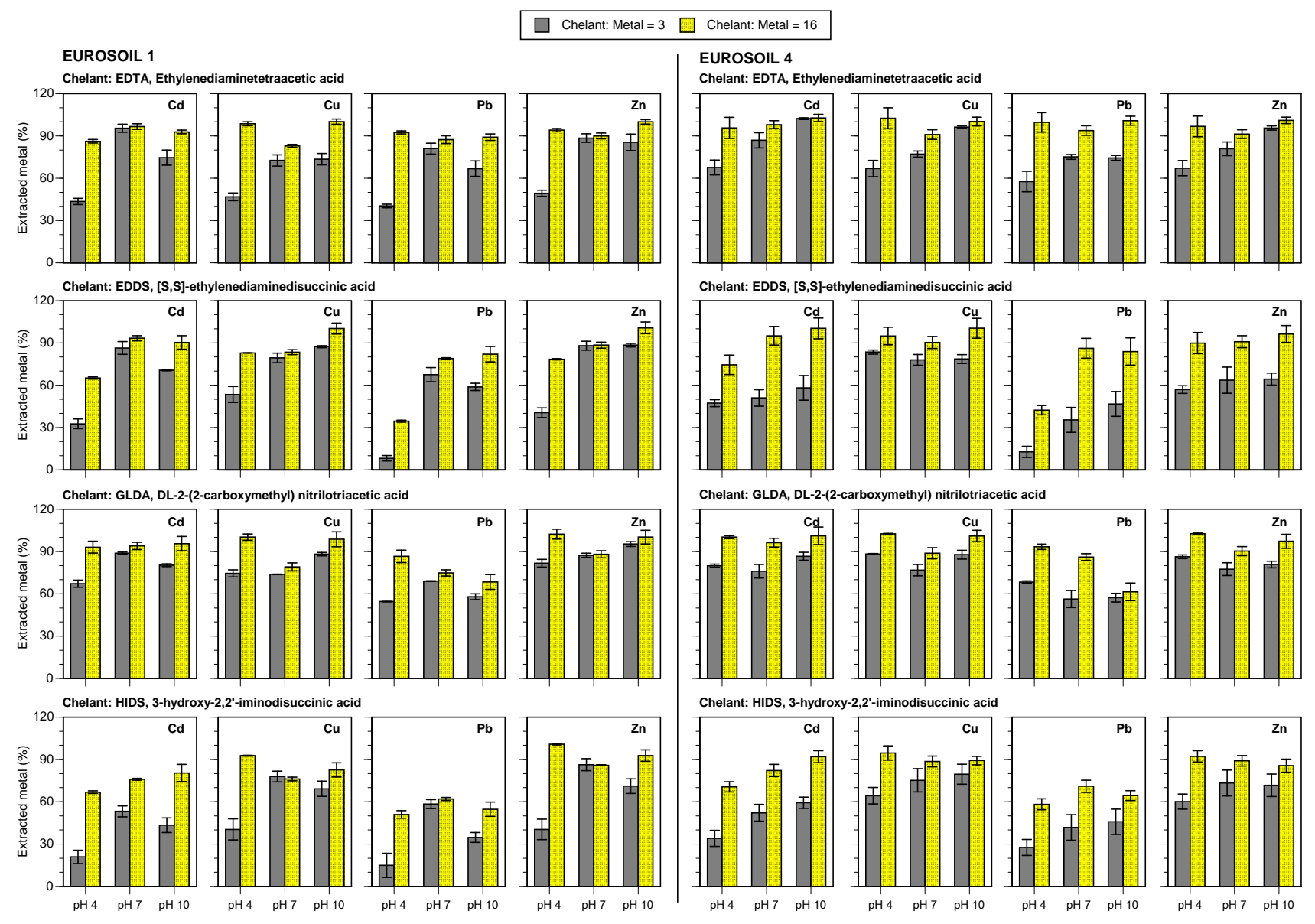

Figure 1. Comparative extraction (\%) of the toxic metals (Cd, $\mathrm{Cu}, \mathrm{Pb}$ and $\mathrm{Zn}$ ) at varying chelant-tometal molar ratios (3 and 16) from the Eurosoil 1 and Eurosoil 4 with different chelants (EDTA, EDDS, GLDA and HIDS) at controlled solution $\mathrm{pH}$. 
$\square \mathrm{pH} 4 \square \mathrm{pH} 7 \square \mathrm{pH} 10$
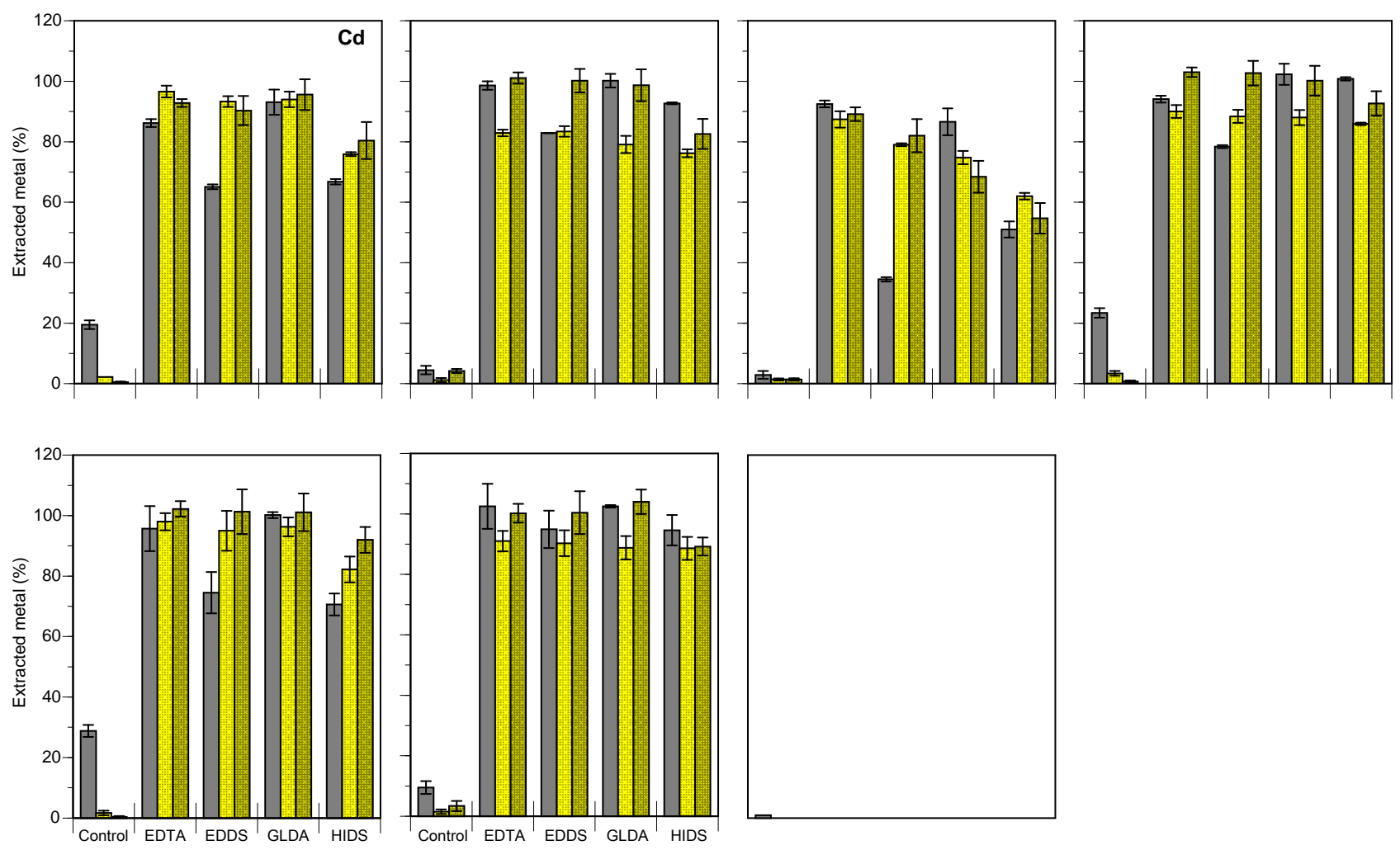

Figure 2. Comparative extraction rate (\%) of the toxic metals $(\mathrm{Cd}, \mathrm{Cu}, \mathrm{Pb}$ and $\mathrm{Zn})$ at varying $\mathrm{pH}$ conditions (4, 7 and 10) from the Eurosoil 1 and Eurosoil 4 with different chelants (EDTA, EDDS, GLDA and HIDS; $0.05 \mathrm{M}$ ). 


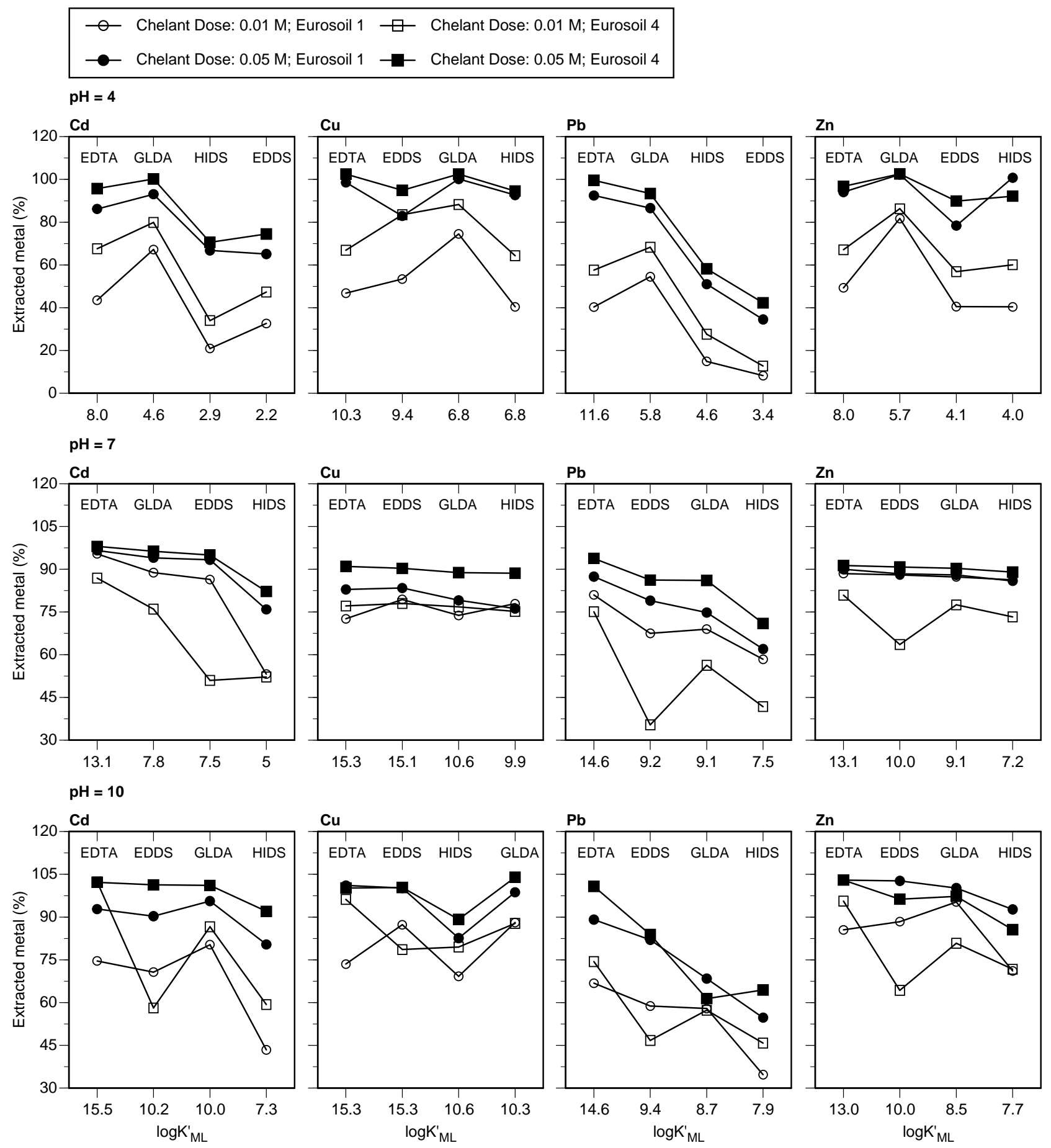

Figure 3. Extraction selectivity of the biodegradable chelants (EDDS, GLDA and HIDS) towards the toxic metals ( $\mathrm{Cd}, \mathrm{Cu}, \mathrm{Pb}$ and $\mathrm{Zn}$ ) in terms of the order (largest to smallest) of conditional metalchelant stability constants $\left(\log K^{\prime}{ }_{\mathrm{ML}}\right)$ from the Eurosoil 1 and Eurosoil 4. 


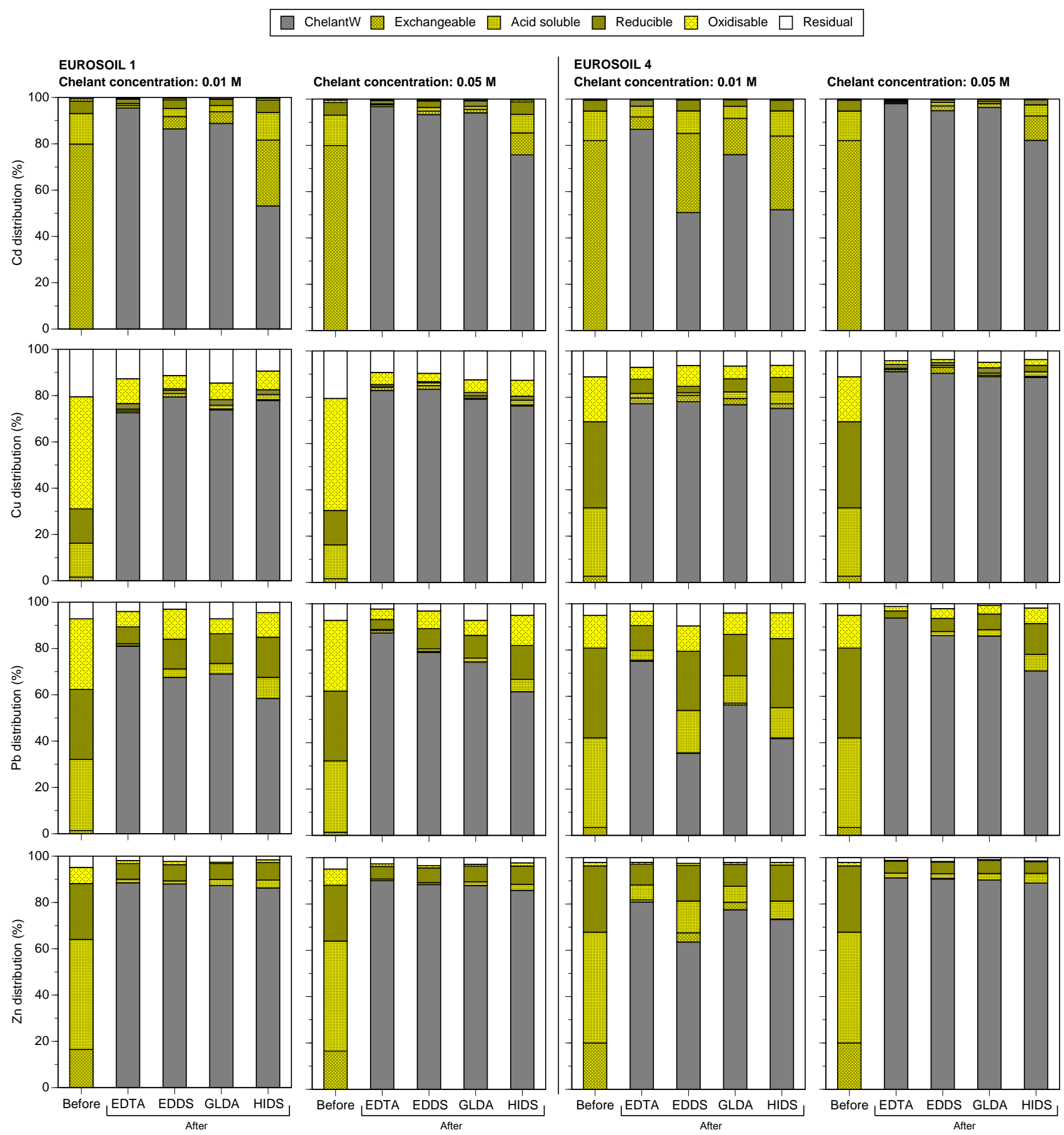

Figure 4. Comparative distribution of the toxic metals ( $\mathrm{Cd}, \mathrm{Cu}, \mathrm{Pb}$ and $\mathrm{Zn}$ ) in the solid phase of Eurosoil 1 and Eurosoil 4 before and after the treatment with different chelants (EDTA, EDDS, GLDA and HIDS; $\mathrm{pH}=7$ ). 


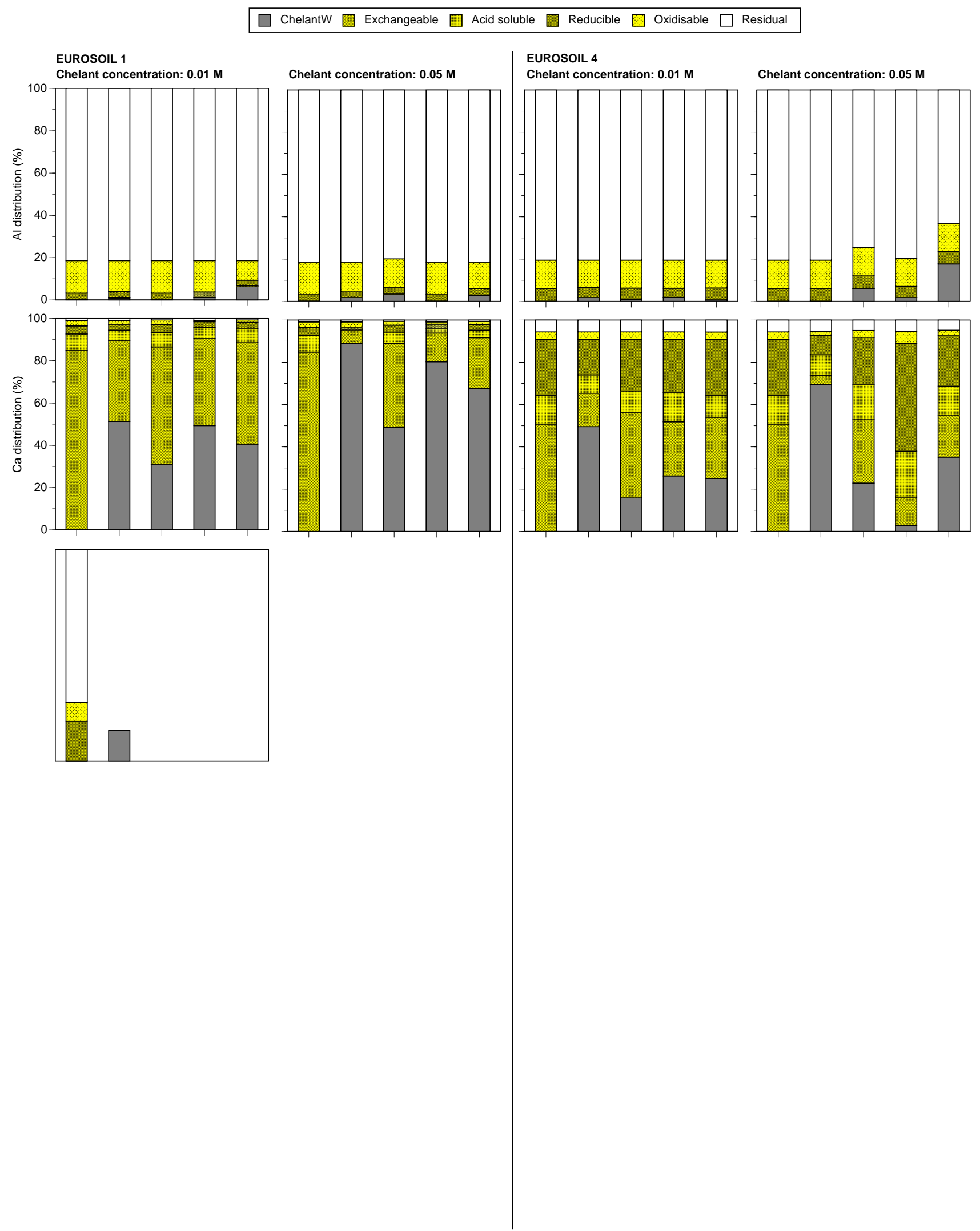

Figure 5. Comparative distribution of the coexisting metals ( $\mathrm{Al}, \mathrm{Ca}, \mathrm{Fe}, \mathrm{Mg}$ and $\mathrm{Mn}$ ) in the solid phase of Eurosoil 1 and Eurosoil 4 before and after the treatment with different chelants (EDTA, EDDS, GLDA and HIDS; $\mathrm{pH}=7$ ). 